\title{
An overview of the concentrations and effects of metals in cetacean species ${ }^{1}$
}

\author{
DAVID Bowles
}

Environmental Imvestigation Agency, 2 Pear Tree Court, London, ECIR ODS, UK

Contacte-mail: international@RSPCA.org.uk

\begin{abstract}
Data are presented on the biomagnification rates, accumulation and concentrations of metals in cetacean species. Concentrations of metals predominantly occur in the soft tissues, although zinc and lead concentrate in the skin and bones. Rates of uptake are dependent upon metal availability, the species' dietary preference and chemical reactions between contaminants. Differences in concentrations occur according to the sex and age of the animal, with certain metals displaying age-related trends. Mercury is the only metal which shows both biomagnification at all levels of the food chain and a positive correlation with age at all stages during a cetacean's life. Differences in concentrations occur between baleen species and toothed cetaceans. Levels tend to be lower in baleen whales, primarily due to a shorter food chain (resulting in lower bioconcentration factors) and as the principal prey species are taken from lower parts of the food chain. A number of storage and detoxifying mechanisms have been recorded in many species that may alter the effects of high metal concentrations. Data on the effects of metal toxicity in cetacean species are sparse, but tolerance limits have been proposed for mercury and cadmium. These are compared with high concentrations recorded in certain species and possible effects extrapolated. Effects of toxicity may alter depending on the species, age and sex of the animal, but indications of toxic effects have been reported. Finally, the possibility of determining regional hot-spots, where background pollution levels are high, from concentrations of mercury reported in cetacean species, are examined.
\end{abstract}

KEYWORDS: POLLUTION; BIOACCUMULATION/MAGNIFICATION; HEAVY METALS; TOXICITY; REVIEW

\section{INTRODUCTION}

This paper is a review of the literature on the incidence of metals in cetacean species, and is intended to provide a focused addition to previous reviews by Wagemann and Muir (1984) and Law (1996) on metals in all species of marine mammals. The paper is intended to provide an overview of bioaccumulation rates, concentrations and effects of metals in cetacean species. Firstly, the major routes of uptake and site specificity of metal concentrations will be examined. A comparison will then be made between concentrations of metals on three levels: at an individual animal level; an intra-species level; and at the sub-order level between Odontoceti and Mysticeti. Known associated physiological effects of these concentrations on cetaceans will then be analysed following a review of the reported detoxification mechanisms.

However, difficulties arise in attempting to interpret data, particularly regarding the significance and possible effects of levels recorded. Firstly, data tend to be limited to certain species and certain metals. Although data are presented on levels of lead, cadmium, zinc, selenium, manganese, iron and copper, the majority of research has focused on mercury (see

${ }^{1}$ A version of this paper was presented to the IWC Scientific Committee as SC/46/O 20. 
Appendix 1). Moreover, research has concentrated on particular species, such as toothed cetaceans, and in particular regions, for instance the Northwest Pacific and North Atlantic Oceans (Appendix 1). Secondly, it is problematic to compare data which have used different sampling, measuring and analytical techniques, and whose results are presented in different formats, such as wet or dry weight, original data, ranges, means or medians. Moreover, data may originate from samples of both freshly killed and stranded cetaceans, the latter likely to present altered levels of metal burdens. Thirdly, differences may occur in concentrations of metals due to factors such as the species' diet, age and sex, but this information is often lacking, particularly on the age of the sampled animal. Finally, as research on the effects of metal burdens on cetacean species is fairly recent, there are few long-term databases that can be used to depict trends and effects of metals on cetaceans.

As top predators, cetaceans can be affected by metals in two distinct ways. Firstly, they may suffer the direct effects from bioaccumulation through the marine food chain and, secondly, they may be indirectly affected by a reduction in prey availability caused by metal toxicity in species at lower trophic levels. This study will consider only the former.

Finally, the pattern of geographical variation in the metal levels found in cetaceans from different regions is examined.

\section{OVERVIEW OF METALS}

Two broad groups of metals are recognised: 'essential' and 'non-essential' metals. Essential metals are those which have a clearly documented and defined function in the body and life of a species. Species require relatively low levels of these metals as an integral part of certain biological and biochemical processes, and a deficiency in them will result in negative effects. Disease and other negative effects may also develop if the concentration of the metal exceeds the level that the species requires or is able to store. Essential metals tend to show less variation in concentrations and burdens within and between species because organisms are able to regulate them. Research has established that copper, iron, selenium and zinc all fulfil vital functions and can therefore be defined as essential metals (Thompson, 1990; Law, 1996).

Non-essential metals are those which have little or no known recorded biological function in a species. These metals, which include mercury, lead and cadmium. are often toxic even at relatively low concentrations.

Metal contamination occurs from natural and anthropogenic sources. The former include geological weathering and volcanic activity, e.g. high levels of mercury are expelled from sub-marine volcanic activities (Piotrowski and Coleman, 1980). Man-made sources of metals are predominantly from waste disposal, leakage from mining operations, the production, use and disposal of chemicals including pesticides, the burning of fossil fuels and the use of anti-fouling paints on shipping.

\section{CONCENTRATION DIFFERENCES AT INTRA- AND INTER-SPECIES LEVELS}

Levels of metals in cetaceans are the net difference between uptake of the metal and any subsequent loss, such as excretion of the metal. A number of factors affect rates of uptake and bioaccumulation. These include: the subject metal, its specification, inter-metal competition for available body sites, inter-metal synergistic effects; and the subject organism and its biological characteristics, particularly sex, age and diet.

There are three routes for the uptake of metils into cetacean bodies. The principal one is dietary, but accumulation has also been reported through the skin and into the lungs (Augier et al., 1993; Law, 1996). The skin is probably of little importance as cetacean skin is an effective barrier and direct bioaccumulation by the cutaneous route probably only occurs 
when lesions are present (André et al., 1990). The pulmonary route is also not that significant although direct incorporation of metals may also occur from those present in the atmosphere (André et al. 1990; Augier et al., 1993). The bioaccumulation and biomagnification of metal compounds in cetaceans primarily occurs through diet, and will vary on a species-specific and metal-specific basis.

\section{Bioaccumulation rates}

Muir et al. (1992) calculated bioaccumulation rates for mercury and cadmium from a relatively simple food web in the Arctic as shown in Table 1.

The data displayed in Table 1 show that only mercury has a consistently high biomagnification factor (BMF) throughout the marine food chain. BMFs from seawater to cetaceans for mercury have been reported in only two cases. These are from seawater to the liver of minke whales $\left(4.3 \times 10^{4}\right)$ in the Antarctic (Honda et al., 1987), and from seawater to the livers of narwhals $\left(3.5 \times 10^{5}\right)$ from the Arctic (Muir et al., 1992). However, Viale (1974) and Augier et al. (1993) calculated a lower mercury BMF of between 100-1,000 times in aquatic food chains, and their figure of a BMF of 4-8 times between fish and cetaceans is also considerably lower than that reported by Muir et al. (1992) who quote a value of 305 for fish to narwhal. The majority of mercury concentrations reported in marine species are of the organic form, methylmercury (Lindberg et al., 1987; André et al., 1990), which is highly lipophilic, therefore readily accumulated in the fatty tissues of fish and cetacean species, and consequently easily transferred along the food chain.

Cadmium BMFs have been reported from seawater to the liver of minke whales in Antarctica $\left(5.5 \times 10^{5} ;\right.$ Honda et al., 1987) and to the liver of narwhals in the Arctic $\left(4 \times 10^{6}\right.$; Muir et al., 1992). These high values are due to the species' reliance on prey which are rich in cadmium. However, as Table 1 shows, a high BMF does not occur at every stage in the food chain. This confirms other reports that the highest concentrations of cadmium are recorded at the phyto- and zooplankton trophic level (Furness and Rainbow, 1990).

There are few published BMFs for other metals, although Muir et al. (1992) stated that the BMF for lead was low between fish and small cetaceans (Table 1).

Table 1

Biomagnification factors for certain metals in the Arctic food chain as calculated by Muir et al., 1992.

\begin{tabular}{lcccc}
\hline & Water-algae & Algae-copepods & Amphipods-fish & Fish-small cetacean \\
\hline Cadmium & $2.4 \times 10^{5}$ & 1.1 & 0.04 & 80 \\
Mercury & - & - & 163.0 & 305 \\
Lead & - & - & - & 0.07 \\
\hline
\end{tabular}

\section{Site specificity of burden levels}

As diet is the main source of uptake of metals in cetaceans, this will affect the pattern of site distribution of these concentrations recorded in the cetacean body. Metals ingested will be transported via the blood system to the soft tissues, so it is expected that these tissues would contain higher concentrations (André et al., 1990).

Table 2 presents data recording the tissue or organ for fourteen species where the highest mean concentration of a particular metal was recorded. It shows that in the majority of baleen and toothed species, the liver consistently contained the highest concentrations of mercury, 
Table 2

Tissue specificity for seven metals and thirteen species, showing the tissue containing the highest mean concentration. Li: Liver, Ki: Kidney, Sk: Skin, Bo: Bones, Bl: Blood, Mus: Muscle, ND: No data reported.

\begin{tabular}{|c|c|c|c|c|c|c|c|}
\hline Species & $\mathrm{Hg}$ & $\mathrm{Cd}$ & $\mathrm{Se}$ & $\mathrm{Zn}$ & $\mathrm{Cu}$ & $\mathrm{Fe}$ & $\mathrm{Pb}$ \\
\hline $\begin{array}{l}\text { Spotted dolphin } \\
\text { Stenella attenuata }\end{array}$ & $\mathrm{Li}^{1}$ & ND & ND & ND & ND & ND & ND \\
\hline $\begin{array}{l}\text { Striped dolphin } \\
\text { Stenella coeruleoalba }\end{array}$ & $\mathrm{Li}^{2,6}$ & $\mathrm{Ki}^{6,13}$ & $\mathrm{Ki}^{11}$ & $\begin{array}{l}\mathrm{Li}^{6,13} \\
\mathrm{Sk} / \mathrm{Bo}^{17}\end{array}$ & $L i^{6}$ & $\mathrm{Li}^{6}$ & $\mathrm{Li}^{6}$ \\
\hline $\begin{array}{l}\text { White whale } \\
\text { Delphinapterus leucas }\end{array}$ & $\mathrm{Li}^{9,14}$ & $\mathrm{Ki}^{14,19}$ & $\mathrm{Li}^{14,19}$ & $\mathrm{Mus}^{14}$ & $\mathrm{Li}^{19}$ & ND & $\mathrm{Ki}^{19}$ \\
\hline $\begin{array}{l}\text { Narwhal } \\
\text { Monodon monoceros }\end{array}$ & $\mathrm{Li}^{3,14}$ & $\mathrm{Ki}^{4,14}$ & $\mathrm{Li}^{3.14}$ & $\mathrm{Ki}^{14}$ & $\mathrm{Li}^{3}$ & ND & $\mathrm{Li}^{4}$ \\
\hline $\begin{array}{l}\text { Fransiscana } \\
\text { Pontoporia blainvillei }\end{array}$ & $\mathrm{Li}^{4}$ & $\mathrm{Ki}^{4}$ & ND & $\mathrm{Li}^{4}$ & $\mathrm{Li}^{4}$ & $\mathrm{ND}$ & $\mathrm{ND}$ \\
\hline $\begin{array}{l}\text { Ganges river dolphin } \\
\text { Platanista gangetica }\end{array}$ & ND & $\mathrm{Ki}^{5}$ & ND & $\mathrm{Li}^{5}$ & $\mathrm{Li}^{5}$ & $\mathrm{Li}^{5}$ & $\mathrm{Ki}^{5}$ \\
\hline $\begin{array}{l}\text { Dall's porpoise } \\
\text { Phocoenoides dalli }\end{array}$ & $\mathrm{Li}^{10}$ & $\mathrm{~K} \mathbf{i}^{10}$ & ND & $\mathrm{Sk}^{10}$ & $\mathrm{Li}^{10}$ & $\mathrm{BI}^{10}$ & $\mathrm{Sk} / \mathrm{Bo}^{10}$ \\
\hline $\begin{array}{l}\text { Long-finned pilot whale } \\
\text { Globicephala melas }\end{array}$ & $\mathrm{Li}^{8}$ & $\mathrm{Ki}^{8.12}$ & $\mathrm{Li}^{.1 .12}$ & $\mathrm{Li}^{8.12}$ & $\begin{array}{l}\mathrm{Li}^{12} \\
\mathrm{Ki} / \mathrm{Li}^{8}\end{array}$ & $\mathrm{ND}$ & $\mathrm{Li}^{8}$ \\
\hline $\begin{array}{l}\text { White-beaked dolphin } \\
\text { Lagenorhynchus albirostris }\end{array}$ & $\mathrm{Li}^{\mathrm{x}}$ & $\mathrm{Ki}^{8}$ & $\mathrm{Li}^{8}$ & $\mathrm{Li}^{8}$ & $\mathrm{Li}^{8}$ & $\mathrm{ND}$ & $\mathrm{Li} / \mathrm{Ki}^{8}$ \\
\hline $\begin{array}{l}\text { Pygmy sperm whale } \\
\text { Kogia breviceps }\end{array}$ & $\mathrm{Li}^{+}$ & $\mathrm{Ki}^{4}$ & ND & $\mathrm{Ki}^{4}$ & $\mathrm{Li}^{4}$ & $\mathrm{ND}$ & ND \\
\hline $\begin{array}{l}\text { Minke whale } \\
\text { Balaenoptera acutorostrata }\end{array}$ & $\mathrm{Li}^{14}$ & $\mathrm{Ki}^{14}$ & $\mathrm{Ki}^{14}$ & $\mathrm{Li}^{14}$ & ND & ND & ND \\
\hline $\begin{array}{l}\text { Cuvier's beaked whale } \\
\text { Ziphius cavirostris }\end{array}$ & ND & $\mathrm{Li} / \mathrm{Ki}^{18}$ & ND & $\mathrm{Li} / \mathrm{Ki}^{18}$ & $\mathrm{Li}^{18}$ & $\mathrm{Li}^{18}$ & ND \\
\hline $\begin{array}{l}\text { Fin whale } \\
\text { Balaenoptera physalus }\end{array}$ & $\mathrm{Li}^{7}$ & ND & ND & ND & ND & ND & ND \\
\hline $\begin{array}{l}\text { Harbour porpoise } \\
\text { Phocoena phocoena }\end{array}$ & $\mathrm{Li}^{15,16}$ & $\mathrm{Ki}^{15,16}$ & $\mathrm{Sk}^{16}$ & $\mathrm{Sk}^{16}$ & $\mathrm{Li}^{16}$ & ND & ND \\
\hline
\end{tabular}

${ }^{1}$ Andre et al., 1990. ${ }^{2}$ Augier et al., 1993. ${ }^{3}$ Wagemann et al., 1983. ${ }^{4}$ Marcovecchio et al., 1990. ${ }^{5}$ Kannan $e t$ al., 1993. "Honda et al., 1983. ${ }^{7}$ Sanpera et at., 1993. ${ }^{8}$ Muir et al., 1988. ${ }^{9}$ Wagemann et al., 1984. ${ }^{10}$ Fujise et al., 1988. "Itano et al., 1984a. ${ }^{12}$ Caurant et al., 1993. ${ }^{13}$ Honda and Tatsukawa, 1983. ${ }^{14}$ Hansen et al., 1990.

${ }^{15}$ Teigen et al., 1992. ${ }^{16}$ Paludan-Muller et al., 1993. ${ }^{17} \mathrm{Honda}$ et al., 1986a. ${ }^{18} \mathrm{Knap}$ \& Jickells, 1983.

${ }^{19}$ Wagemann et al., 1990.

iron and copper. In many of these species the second highest concentration was reported in the kidney.

André et al. (1990) and Augier et al. (1993) report that mercury concentrations in the striped dolphin (Stenella coeruleoalba) declined in the following order: liver $\geq$ spleen $\geq$ blubber, kidney, pancreas $\geq$ stomach, lungs $\geq$ skeletal muscles, intestine, heart, brain, skin $\geq$ melon fat, blood.

Differences in concentrations between tissues can be high. In a study of mercury levels in spotted dolphins (Stenella attenuata) in the Pacific Ocean, André et al. (1990) reported that $95 \%$ of the burden analysed in 18 different tissues and organs was in the liver, skeletal muscle and blubber; levels in the liver $\left(62 \mu \mathrm{g} \cdot \mathrm{g}^{-1}\right.$ the highest concentrations) were 170 times higher than those in the blood, which contained the lowest concentrations $\left(0.36 \mu \mathrm{g} . \mathrm{g}^{-1}\right)$ and were six times higher than lhose in the spleen (which contained the second highest concentration). Similar differences have been reported for other species. In long-finned pilot whales (Globicephala melas) hepatic concentrations were ten times higher than those in the kidney, which contained the second highest concentration, and in white-beaked dolphins 
(Lagenorhynchus albirostris) the concentations were three times higher than those in the kidney (Muir et al., 1988). Similar differences in concentrations have been recorded between other body sites. For instance, mercury concentrations were 25 times lower in the melon than in the muscle of striped dolphins from the Mediterranean (André et al., 1991).

The kidney contained the highest cadmium concentrations in all species recorded in Table 2. These concentrations were also significantly higher than those reported in the liver, which generally contained the second highest concentrations. For instance, mean renal cadmium concentrations were four times higher than those in the liver in striped dolphins from the west Pacific Ocean (Honda et al., 1983), four times higher in harbour porpoises (Phocoena phocoena) from Greenland (Paludan-Muller et al., 1993) and three times higher in narwhals (Monodon monoceros) from Greenland (Hansen et al., 1990). The high concentration of cadmium in the kidney may be connected to the presence of certain storage mechanisms using cadmium metallothionein protein (Fujise et al., 1988; Marcovecchio et al., 1990). This will be discussed further under the section on detoxifying strategies.

Table 2 also shows that high concentrations of certain metals are reported in the skin, blood and bones. Zinc concentrations were highest in the skin and bones in studies where all the organs and tissues were analysed, and highest in the liver where only soft tissues were analysed. Only in white whales (Delphinapterus leucas) sampled around Greenland were the highest concentrations found in the muscle (Hansen et al., 1990). Large differences were also reported between the organ or tissue containing the highest and second highest concentrations. In two Dall's porpoises (Phocoenoides dalli) from the western Pacific Ocean, over half the total body burdens of zinc recorded were in the skin and similarly zinc concentrations in the skin of harbour porpoises from Greenland were seven times higher than those found in the liver (Paludan-Muller et al., 1993).

There are few comparative data between tissues for other metals (Table 2). High lead concentrations ( $40 \%$ of total burdens) were recorded in the skin and bones of Dall's porpoises (Fujise et al., 1988), and high iron concentrations were reported in the blood and lungs of the same species. Selenium accumulation varies. Only one study has analysed selenium concentrations in all organs and tissues (Paludan-Muller et al., 1993), and this found that the highest concentration occurred in the skin, five times greater than those in the kidney. Other studies, solely of soft tissues, recorded the highest concentrations to be in the liver, unsurprising in view of the strong correlation selenium displays with mercury concentrations.

\section{Intra-species differences in concentrations}

Two examples of intra-species differences in concentrations are given in Tables 3 and 4. Hepatic concentrations of mercury are several factors higher in minke whales from the Arctic than the Antarctic, the maximum concentrations in minke whales from the former region being 20 times higher than the maximum recorded in the Antarctic region. However, cadmium concentrations showed the reverse relationship. Maximum concentrations in Antarctic minke whales were about 20 times those recorded in the Arctic (Table 3).

The major difference between minke whale populations in the Arctic and Antarctic is their diet. Arctic minke whales feed principally on sand eels, Ammodytes, (Hansen et al., 1990) whereas those in the Antarctic feed primarily on krill, Euphasia spp. (Honda et al., 1987). Higher concentrations of cadmium and lower ones of mercury are found in krill when compared to fish (Honda et al., 1987) and these differences are reflected in the concentrations outlined in Table 3. Honda et al. (1987) also stated that differences in the length of the food chain between the two regions may be relevant. The food chain in the Antarctic is short, providing less opportunity for biomagnification. 
Table 3

Range and means of hepatic concentrations of cadmium and mercury in the minke whale population from three different areas $\left(\mathrm{ng} \mathrm{g}^{-1}\right.$ wet weight). ND: No data recorded. "The figure is the median, not the mean.

\begin{tabular}{lccc} 
& Greenland $^{3}$ & Arctic $^{2}$ & Antarctic $^{3}$ \\
\hline Cadmium & ND & $500-1,450$ & $2,200-33,000$ \\
Mercury & $70-410$ & $900^{*}$ & $20-129$ \\
& 180 & $140-2,680$ & $46.5^{4}$ \\
\hline
\end{tabular}

'Johansen et al., $1980(n: 6) .{ }^{2}$ Hansen et al., $1990(n: 24) .{ }^{3}$ IIonda et al., 1987 ( $\left.n: 135\right)$.

Table 4

Cadmium and mercury concentrations in the livers of harbour porpoises from two different areas ( $\mu \mathrm{g} \mathrm{g}^{-1}$ wet weight).

\begin{tabular}{lcc}
\hline & Greenland $^{\prime}$ & UK coast $^{2}$ \\
\hline Mercury & range $=0.48-20.7$ & range $=0.6-150$ \\
mean $=6.23$ & mean $=13.8$ \\
Cadmium & range $=0.06-11.7$ & range $=0.03-1.2$ \\
& mean $=4.29$ & mean $=0.18$ \\
\hline
\end{tabular}

'Paludan-Muller et al., 1993 ( $n: 43) .{ }^{2}$ Law et al., 1991 ( $\left.n: 20\right)$.

Table 4 shows differences in mercury and cadmium concentrations in two discrete populations of harbour porpoises. Cadmium levels in those from Greenland were significantly higher than those found around the UK (by more than 20 times) but mercury concentrations were about half those from UK porpoises. The reason for this is less apparent than the minke whale example shown above, but may be due to higher mercury levels found in the environment around the UK and the fact that porpoises from Greenland feed on fish which contain higher cadmium levels than fish species found around UK coasts (Paludan-Muller et al., 1993).

\section{Differences in concentration levels between toothed and baleen cetaceans}

Table 5 shows differences in the cadmium and mercury bioconcentration factors between odontocetes and mysticetes. Both in the Arctic and Antarctic they were higher in odontocetes than in mysticetes. This is clearly reflected in the concentration of metals in tissues. Honda et al. (1983) recorded a range of mercury concentrations in the liver of striped dolphins from the western Pacific Ocean (Table 6) of $1.7 \mu \mathrm{g}^{-1}$ to $485 \mu \mathrm{g} . \mathrm{g}^{-1}$ (mean: $205 \mu \mathrm{g} . \mathrm{g}^{-1}$ ) whereas Honda et al. (1987) reported concentrations in the livers of minke whales in the Antarctic from $0.02 \mu \mathrm{g} . \mathrm{g}^{-1}$ to $1.3 \mu \mathrm{g} . \mathrm{g}^{-1}$ (mean: $0.4 \mu \mathrm{g} . \mathrm{g}^{-1}$ ), a difference of over 500 times. Other baleen whales, such as bowhead whales sampled in the Arctic, show similarly low mercury levels (Byrne ct al., 1985). Indeed generally, the minimum concentration of mercury in the liver of toothed cetaceans is higher than the maximum concentration recorded in baleen whales.

Three principal reasons explain these differences (Honda ct al., 1987): (1) diet: toothed cetaceans' greater reliance on fish as a prey species; (2) geography: toothed cetaceans' predominance in coastal areas; and (3) length of food chain: toothed cetaceans ' position as a top predator in longer food chains than those found in baleen whales. 
Table 5

Bioconcentration factors for three metals from sea water to cetaceans (concentrations measured in the livers of narwhals and minke whales). ND: No data recorded.

\begin{tabular}{lccc}
\hline & Cadmium & Mercury & Lead \\
\hline Odontoceti $^{1}$ & $4.0 \times 10^{\circ}$ & $3.0 \times 10^{5}$ & $1.9 \times 10^{3}$ \\
Mysticeti $^{2}$ & $5.5 \times 10^{5}$ & $4.3 \times 10^{4}$ & $\mathrm{ND}$ \\
\hline
\end{tabular}

Arctic ecosystem: Muir et al., 1992. 'Antarctic ecosystem: Honda et al., 1987.

Table 6

Tentative trends in the relationship of the concentrations of nine metals with age category in the liver of striped dolphins from the west Pacific Ocean. (data taken from Honda e' al., 1983.) +ve: increase in concentration in this age bracket; -ve: decrease in concentration in this age bracket; -: no discernible change in concentration recorded; ND: no data recorded.

\begin{tabular}{lccccccccc}
\hline Age of cetacean & $\mathrm{Fe}$ & $\mathrm{Zn}$ & $\mathrm{Pb}$ & $\mathrm{Mn}$ & $\mathrm{Ni}$ & $\mathrm{Cd}$ & $\mathrm{Hg}$ & $\mathrm{Se}$ & $\mathrm{Cu}$ \\
\hline Gestation period & $+\mathrm{ve}$ & $+\mathrm{ve}$ & $+\mathrm{ve}$ & $+\mathrm{ve}$ & $\mathrm{ND}$ & - & $+\mathrm{ve}$ & $\mathrm{ND}$ & $+\mathrm{ve}$ \\
Suckling (calf) & $-\mathrm{ve}$ & $+\mathrm{ve}$ & $+\mathrm{ve}$ & $+\mathrm{ve}$ & $+\mathrm{ve}$ & $+\mathrm{ve}$ & $+\mathrm{ve}$ & $\mathrm{ND}$ & $+\mathrm{ve}$ \\
Up to 8 years & $+\mathrm{ve}$ & $-\mathrm{ve}$ & - & $-\mathrm{ve}$ & - & - & $+v e$ & $+v e$ & $-v e$ \\
Adult & - & - & $+\mathrm{ve}$ & - & $+\mathrm{ve}$ & $+\mathrm{ve}$ & $+\mathrm{ve}$ & $+\mathrm{ve}$ & - \\
\hline
\end{tabular}

Focardi et al. (1992) reported levels of mercury in baleen and toothed cetaceans from the Mediterranean Sea, the geographical region where the highest burden of mercury in a small cetacean has been recorded. Levels of mercury and cadmium were on average 5-20 times lower in baleen whales and three times lower than those recorded in toothed cetacean species in the same locality (Focardi et al., 1992). Indeed small cetaceans have recorded levels of mercury and selenium which are higher than in any other organism (Koeman et al., 1973; André et al., 1991).

Although accumulation rates and concentration levels for most metals are generally lower in baleen whales, as reported earlier, species-specific differences can occur as a result of diet. Cadmium levels are usually higher in krill than in fish (Thompson, 1990; Hapke, 1991) and this explains the comparatively higher cadmium levels present in the krill-eating minke whales from the Antarctic than in the fish-eating cetaceans from the Pacific Ocean (Honda et al., 1987).

However, when cephalopod-eating odontocetes are compared with krill-eating mysticetes, concentrations are much higher in the former, again reflecting dissimilar cadmium richness in their diets. Caurant et al. (1993) recorded cadmium concentrations in the kidney of longfinned pilot whales in the North Atlantic to be up to 30 times higher than those recorded for minke whales. They reported a range of concentrations in the kidney from one school of pilot whales 1.4-158 $\mu \mathrm{g} \cdot \mathrm{g}^{-1}$ (mean: $93.1 \mu \mathrm{g} . \mathrm{g}^{-1}$ ) which compares with a range of 1.7-5.6 $\mu \mathrm{g} . \mathrm{g}^{-1}$ (median: $3.7 \mu \mathrm{g} . \mathrm{g}^{-1}$ ) for cadmium concentrations in the kidneys of minke whales in the Arctic (Hansen et al., 1990) and 2.2-33 $\mu \mathrm{g} . \mathrm{g}^{-1}$ in hepatic tissues of minke whales from the Antarctic (Honda et al., 1987).

The greater reliance of baleen whales on krill may also be responsible for higher levels of nickel found in these species than in toothed whales (Honda et al., 1987), although data on nickel levels in toothed cetaceans are sparse, making comparison difficult. 


\section{PHYSIOLOGICAL EFFECTS}

Toxicity occurs in a species when the accumulation of a metal is not matched by the body's storage, excretory, metabolic and detoxification mechanisms (Underwood, 1977; Piotrowski and Coleman, 1980). Once this stage is reached, spill-over of the metal occurs to other cells, particularly in soft tissues such as the liver and kidney (Underwood, 1977; Piotrowski and Coleman, 1980).

A number of factors will determine the actual toxic effects on a species. These will include the levels of metal ingested; the period of ingestion; any storage, metabolic, excretory or detoxifying mechanisms; synergistic interactions with concentrations of other metals; the tissue site; relationships and effects resulting from failure at other different tissue sites (Langston, 1990). Synergistic effects from high concentrations of other pollutants such as polyaromatic hydrocarbons have also been reported (George, 1990).

Little research has been undertaken on the effects of metals in cetacean species. The capacity for excretion of mercury appears to be low, so most ingested mercury remains in the animal (Nigro and Leonzio, 1993). Probably because mercury occurs naturally in the environment, to compensate for poor excretory mechanisms, storage and detoxifying strategies have evolved in many cetaceans. These allow metals to be stored in an inert state in tissues. Thus, the presence of high concentrations of a metal is not necessarily correlated with toxicity.

\section{Detoxifying strategies}

In many cetacean species, correlations have been reported between metal concentrations in the tissues and organs analysed (Table 7). Some of these relate to detoxification mechanisms.

Mercury

Most mercury available in the ecosystem is inorganic, but is converted by micro-organisms present in freshwater and marine sediments to methylmercury, a more toxic and readily bioaccumulative form (Law, 1996). The effect of detoxification can be seen in the high values of inorganic mercury recorded in cetaceans, despite the fact that most mercury is ingested in its organic form.

A decline in the ratio of methylmercury to total mercury has been recorded in the soft tissues of harbour porpoises (Joiris et al., 1991), pilot whales (Julshamn et al., 1987; Caurant et al., 1993), narwhals (Wagemann et al., 1984), striped dolphins (Itano et al.. 1984b) and common dolphins (Joiris et al., 1992b) and in the hard tissues of striped dolphins (Honda et al., 1986b), confirming that a de-methylating process occurs within the tissues of the animal. In one adult narwhal examined by Wagemann et al. (1984), methylmercury only represented $7 \%$ of total mercury values in the liver and $11 \%$ in the kidney.

Joiris et al. (1992b) interpreted mercury detoxification in common dolphins as follows: methylmercury concentrates in the fatty areas of the animal, where it is mineralised and re-mobilised to accumulate as inorganic mercury in the liver. Here it is detoxified by binding to selenium or metallothionein proteins.

The binding of mercury to selenium can be seen in the high levels of selenium that have been widely reported in conjunction with high levels of mercury in a number of cetacean species (Table 6), but appears to only occur on specific tissues in certain species and only after a certain age. It has been reported in the bone, kidney, liver and muscle of striped dolphins (Itano et al., 1984b; Honda et al., 1986b; Leonzio et al., 1992), and the livers of pilot whales (Muir et al., 1988; Caurant et al., 1993), narwhals (Wagemann et al., 1990) and harbour porpoises (Paludan-Muller et al., 1993). However, no relationship was found in the 
Table 7

Inter-metal correlations reported in cetaccans. Key = Ki: Kidncy, Li: Liver, Mu: Muscle, Bo: Bone, Blu: Blubber; +ve: positive correlation recorded; -ve: negative correlation recorded.

\begin{tabular}{|c|c|c|c|}
\hline & Tissue & Species & Reference \\
\hline \multirow[t]{9}{*}{ Mercury-selenium +ve } & $\mathrm{Li} ; \mathrm{Ki} ; \mathrm{Mu}$ & White whale & Wagemann et al., 1990 \\
\hline & $\mathrm{Li} ; \mathrm{Ki}$ & Narwhal & Wagemann et al., 1983 \\
\hline & $\mathrm{Li}$ & Common dolphin & Joiris et al., $1992 \mathrm{~b}$ \\
\hline & $\mathrm{Li}$ & Bottlenose dolphin & Nigro \& Leonzio, 1993 \\
\hline & Li: Bo & Striped dolphin & $\begin{array}{l}\text { Nigro \& Leonzio, } 1993 \\
\text { Honda et al., 1986a }\end{array}$ \\
\hline & $\mathrm{Li}$ & Harbour porpoise & Teigen et al., 1992 \\
\hline & $\mathrm{Li}$ & Minke whale & Hansen et al., 1990 \\
\hline & $\mathrm{Li} ; \mathbf{K i}$ & Pilot whale & Caurant et al., 1993 \\
\hline & $\mathrm{Li}$ & Cuvier's beaked whale & Martoja \& Viale, 1977 \\
\hline \multirow[t]{4}{*}{ Cadmium-selenium +ve } & $\mathrm{Ki}$ & Beluga & Wagemann et al., 1990 \\
\hline & $\mathrm{Li} ; \mathrm{Mu}$ & Pilot whale & Caurant et al., 1993 \\
\hline & $\mathrm{Li}$ & White whale & \\
\hline & & Minke whale & Hansen et al., 1990 \\
\hline Cadmium-mercury -ve & $\mathrm{Ki}$ & Beluga & Wagemannet al 1990 \\
\hline \multirow{2}{*}{ Cadmium-mercury +ve } & $\mathrm{Li}$; $\mathrm{Blu}$ & Narwhal & Wagemann et al. 1983 \\
\hline & $\mathrm{Li} ; \mathrm{Ki} ; \mathrm{Mu}$ & Pilot whale & Caurant et al., 1993 \\
\hline \multirow[t]{6}{*}{ Cadmium-zinc +ve } & $\mathrm{Li} ; \mathrm{Ki}$ & Striped dolphin & Honda \& Tatsukawa, 1983 \\
\hline & $\mathrm{Li} ; \mathrm{Ki}$ & Beluga & Wagemann et al., 1990 \\
\hline & $\mathrm{Li} ; \mathrm{Ki}$ & Narwhal & Wagemann et al., 1983 \\
\hline & $\mathrm{Ki}$ & Harbour porpoise & Paludan-Muller et al., 1993 \\
\hline & $\mathrm{Li}$ & Minke whale & Honda et al., 1987 \\
\hline & $\mathrm{Li} ; \mathrm{Ki}$ & Pilot whale & Caurant et al., 1993 \\
\hline Lead-cadmium +ve & $\mathrm{Ki}$ & Narwhal & Wagemann et al., 1983 \\
\hline Zinc-mercury -ve & $\mathrm{Ki}$ & Beluga & Wagemann et al., 1990 \\
\hline \multirow[t]{3}{*}{ Zinc-mercury +ve } & $\mathrm{Mu}$ & Beluga & \\
\hline & $\mathrm{Li}$ & Minke whale & Honda et al., 1986b \\
\hline & $\mathrm{Ki}$ & Pilot whale & Caurant et al., 1993 \\
\hline Zinc-selenium +ve & $\mathrm{Ki}$ & Beluga & Wagemann et al., 1990 \\
\hline \multirow[t]{2}{*}{ Silver-mercury +ve } & $\mathrm{Li}$ & Beluga & Becker et al., 1995 \\
\hline & & Pilot whale & \\
\hline
\end{tabular}

muscle of harbour porpoises (Schnapp, 1993) or in the liver of long-finned pilot whale foetuses (Caurant and Navarro, 1994).

The interactions between selenium and mercury are still poorly understood. Detoxification could occur due to competition for binding sites, or a formation of a less toxic and more easily storable complex such as mercury selenide (Koeman et al., 1973; Augier et al., 1993). The occurrence of mercury selenide granules within phagocytic cells reported by Nigro and Leonzio (1993) in bottlenose dolphins suggests that the production of mercury selenide, and thus the detoxification of methylmercury, is performed by phagocytosis. As mercury selenide granules have been reported in the liver (Martoja and Viale, 1977; Nigro and Leonzio, 1993), lungs (Augier et al., 1993) brain and muscle (Nigro and Leonzio, 1993) of cetacean species, it appears that storage and detoxification of mercury occurs at different sites. However, cetaceans cannot excrete mercury selenide (Martoja and Berry, 1980; Caurant et al., 1994), so particles will accumulate in their cells.

By binding mercury to metal-binding proteins, damage is reduced and the storage of certain metals regulated. The actual toxic effects of the metal will only occur once the binding capacity of the metallothionein becomes saturated and a spillover of excess ions 
occurs to other cells (Langston, 1990). Metallothioneins have been found in long-finned pilot whales (Caurant et al., 1993), narwhals (Wagemann et al., 1984) and common dolphins (Joiris et al., 1992b).

\section{Other metals}

The sequestration of free ions of metals by metallothionein has been recorded in a number of species for other metals, including, in descending order of binding affinity, copper, cadmium and zinc; no sequestration of lead has yet been reported (Eisler, 1984; Quarterman, 1986; Tohyama et al., 1986; Law, 1996).

Paludan-Muller et al. (1993) reported that the relationship between zinc and cadmium concentrations in the kidneys of harbour porpoises was due to cadmium binding to zinc-metallothionein. This correlation has also been recorded in the liver of narwhals and white whales (Hansen et al., 1990) and in the liver and kidney of other marine mammals (Wagemann and Stewart, 1994). Wagemann et al. (1984) reported that in the liver of a narwhal, a high percentage of both cadmium and copper were thionein-bound, whereas for mercury it was lower. Similarly, in the livers of common dolphins, Joiris et al. (1992b) reported that $50 \%$ of inorganic mercury was not thionein or selenium-bound and was thus potentially toxic.

Other synergistic effects have been reported. A deficiency in levels of iron and zinc, for example, can increase the absorption rate of lead in certain species (Honda and Tatsukawa, 1983; Kostial, 1986; Quarterman, 1986). Honda and Tatsukawa (1983) also reported that cadmium accumulation may inhibit detoxification rates for zinc and copper in striped dolphins. Other variables can increase the toxic potential of a metal. High water temperature and low salinity have been reported to react with metals such as cadmium, mercury and zinc to result in an increase in the metal's toxic potential (Langston, 1990).

\section{Effects of metals in cetacean species}

\section{Mercury}

The high toxicity, long biological half-life, lipophilicity and biomagnification of mercury in the food chain make this metal one of the most threatening. In their review, Wagemann and Muir (1984) proposed that tolerance limits for mercury in mammals may be in the range of $100-400 \mu \mathrm{g} \cdot \mathrm{g}^{-1}$ in hepatic tissue, although the evidence for this is unclear. Table 8 shows that seven studies of three species have reported concentrations above this limit.

Despite the assertion in Wagemann and Muir (1984), studies to ascertain the effects of these concentrations in cetaceans are rare, although in certain non-cetacean species, mercury poisoning has resulted in serious disorders in the liver, kidney and brain, and methylmercury poisoning resulted in behavioural defects, loss of coordination and loss of vision. In other marine mammal species, high hepatic and renal mercury concentrations have caused liver and kidney failure (Law, 1996). Samples of six of the seven case studies of cetaceans shown in Table 8 were taken from stranded dolphins, suggesting a possible causal link with high mercury concentrations (Augier et al., 1993).

Rawson et al. (1993) reported toxic effects of mercury in a pod of bottlenose dolphins stranded off the USA coast. Nine of the 18 animals sampled had extensive deposits of a granular pigment within the livers' portal areas. These animals also contained the highest mercury liver concentrations which ranged from $61-433 \mu \mathrm{g} \cdot \mathrm{g}^{-1}$. Furthermore, four of the nine animals with pigmentation deposits also had active liver disease, including necrosis and fat globules among the hepatocytes adjacent to the portal areas. The presence of fat globules revealed that the animals' fat metabolism had been affected, and may have led to cell death. In the absence of any correlation with age, Rawson et al. (1993) suggested that the pigment accumulation was related to the toxic effect of mercury. 
Table 8

Concentrations of mercury recorded in the liver of cetaceans which exceed the proposed tolerence limits suggested by Wagcmann \& Muir, $1984\left(100-400 \mu \mathrm{g} \cdot \mathrm{g}^{-1}\right)$. All figures are $\mu \mathrm{g} \cdot \mathrm{g}^{-1}$ wet weight except ${ }^{*}=\mathrm{dry}$ wt.

\begin{tabular}{|c|c|c|c|c|}
\hline & $\begin{array}{c}\text { Range of } \\
\text { concentrations }\end{array}$ & $\begin{array}{l}\text { Mean/median } \\
\text { concentration }\end{array}$ & Gcographical area & Reference \\
\hline $\begin{array}{l}\text { White whale } \\
(n: 30)\end{array}$ & $1.42-756^{\circ}$ & $126^{\circ}$ & St Lawrence, Canada ${ }^{2}$ & Wagemann et al., 1990 \\
\hline $\begin{array}{l}\text { False killer whale } \\
(n: 38) \\
\text { Bottlenose dolphin }\end{array}$ & $+1-479$ & 249 & New South Wales, Australia ${ }^{2}$ & Kemper et al., 1994 \\
\hline $\begin{array}{l}(n: 12) \\
(n: 4)\end{array}$ & $\begin{array}{c}0.1-+43 \\
12.2-13,155.6^{*}\end{array}$ & $\begin{array}{l}13+.6 \\
\text { med: } 270.4^{*}\end{array}$ & $\begin{array}{c}\text { US }^{2} \\
\text { Mediterranean }\end{array}$ & $\begin{array}{l}\text { Rawson et al., } 1993 \\
\text { Lconzio et al., } 1992\end{array}$ \\
\hline $\begin{array}{l}\text { Striped dolphin } \\
(n: 45) \\
(n: 25) \\
(n: 13)\end{array}$ & $\begin{array}{l}1.7-475 \\
1.2-1.5+4\end{array}$ & $\begin{array}{c}205 \\
346.1 \\
\text { med: } 327\end{array}$ & $\begin{array}{l}\text { West Pacific' } \\
\text { Mcditcrancan }^{2}\end{array}$ & $\begin{array}{l}\text { Honda et al., } 1983 \\
\text { Andre et al., } 1991\end{array}$ \\
\hline$(n: 19)$ & $\begin{array}{c}48-1,613 \\
324.4-4,400^{\circ}\end{array}$ & $\begin{array}{c}474 \\
\text { med: } 324.4^{*}\end{array}$ & $\begin{array}{l}\text { Mediterranean? } \\
\text { Mediterranean }\end{array}$ & $\begin{array}{l}\text { Augier et al., } 1993 \\
\text { Leonzio et al., } 1992\end{array}$ \\
\hline
\end{tabular}

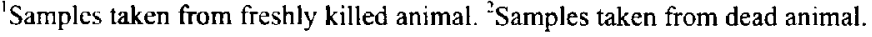

The effects of anthropogenic pollutants have also been studied extensively over a nine year period on the population of white whales in the St Lawrence River, Canada. Pathological abnormalities such as bladder cancer, severe lesions and tumours have been reported (Martineau et al., 1985; 1988; 1994). Twenty-four neoplasms were found in 18 of the +5 animals necropsied in the nine year study, eight neoplasms being malignant (Béland et al., 1993). The population has a high level of bacterial infections, pneumonia and tooth loss, about $2 \%$ have spinal deformities and its reproductive rate is only half that found in other white whale populations (Martineau et al., 1988; Béland et al., 1993). Although mercury levels are extremely high in white whales from the St Lawrence (Table 8), it is difficult to attribute specific effects to mercury poisoning as the concentrations of lead (Wagemann et al., 1990) and other anthropogenic pollutants, notably organochlorines (Béland et al., 1992; 1993), are also high. Wagemann et al. (1990) believed that the adverse effects reported in this population are likely to be a combination of all the toxic elements acting over a long time period (see also the review by Martineau et al. in the present volume).

So, for certain species, there is some evidence that high levels of mercury may have resulted or contributed to chronic illness in disease and mortality in die-offs (Wagemann et al., 1990; Béland et al., 1992; Augier et al., 1993; Law, 1996). However, equally high mercury levels in mature striped dolphins from the North Pacific have apparently not resulted in any side effects (Itano et al., 1984a). This difference may be due to interspecific differences in susceptibility to the effects of metals or that the rate of bioaccumulation of mercury is more important than its actual burden level.

\section{Other metals}

Wagemann and Muir (1984) were unable to suggest tolerance limits for metals other than mercury. In the absence of any specific marine mammal values for cadmium tolerance limits in the kidney, Law (1996) has used the figures suggested for humans where renal damage occurs above concentrations of 200-400 $\mu \mathrm{g} . \mathrm{g}^{-1}$ (Piotrowski and Coleman, 1980). From research on the association of cadmium concentrations in the kidney and liver, Fujise $e$ t al. (1988) proposed that concentrations of cadmium higher than $20 \mu \mathrm{g} \cdot \mathrm{g}^{-1}$ in the liver would 
result in renal dysfunction. Taking the tolerance figure for the kidney, Law (1996) proposed that this corresponded to a liver tolerance figure in the range of $40-200 \mu \mathrm{g} . \mathrm{g}^{-1}$. Maximum and mean concentrations reported in cetaceans above these proposed tolerance limits are shown in Table 9.

According to Caurant et al. (1994), renal cadmium levels varied considerably among schools of Faroese long-finned pilot whales, with several having levels higher than 100 $\mu \mathrm{g} . \mathrm{g}^{-1}$, possibly approaching critical levels. Cadmium concentrations in the blood were also higher than the minimum levels established for adverse effects in humans. Caurant $e t$ al. (1993). whilst suggesting that high levels might reflect an adaptive response of pilot whales, qualified this by noting that those animals which contained high cadmium concentrations had less efficient regulation of copper and zinc (cadmium is bound to available metallothionein thus reducing its function of ensuring homeostasis of copper and zinc). Wagemann et al. (1983) also reported high cadmium concentrations in narwhals from the Arctic. They did not examine metal damage in the narwhals' kidneys but reported that concentrations were high enough to cause renal dysfunction. In non-cetacean species, cadmium poisoning has resulted in adverse effects on reproduction, growth and bone structure (Kostial, 1986), but to date no causal relationship between cadmium and physical effects have been reported in cetaceans, although Caurant et al. (1994) associated gastric erosion and ulcers in pilot whales with high cadmium levels.

Little work has been done on the effects of the other metals in cetaceans. Levels of lead tend to be low although Wagemann et al. (1990) reported that the St Lawrence River white whale population had very high levels, reaching $2.13 \mu \mathrm{g} . \mathrm{g}^{-1}$ dry weight in the liver (mean: $0.59 \mu \mathrm{g} . \mathrm{g}^{-1}$ dry weight; $\mathrm{n}: 30$ ). These concentrations, about 10 times higher than those found in Arctic white whales, were attributed to high aquatic levels of lead resulting from anthropogenic sources (Wagemann et al., 1990). A young bottlenose dolphin stranded along the South Australian coast had levels of $61 \mu \mathrm{g} . \mathrm{g}^{-1}$ in the bone, which Kemper et al. (1994)

\section{Table 9}

Concentrations of cadmium in the liver and kidney which exceed the range of tolerance limits proposed by Piotrowski \& Coleman (1980), Fujise et al. (1988) and Law (1996) (200-400 $\mathrm{g} \mathrm{g} \mathrm{g}^{-1}$ in the kidney and 20-200

$\mu \mathrm{g} \mathrm{g}^{-1}$ in the liver). $\mathrm{x}$ : mean value. All concentrations are wet weight except ${ }^{1}$ converted from dry weight (Law, in press) and ${ }^{2}$ dry weight. All samples analysed from freshly killed animals.

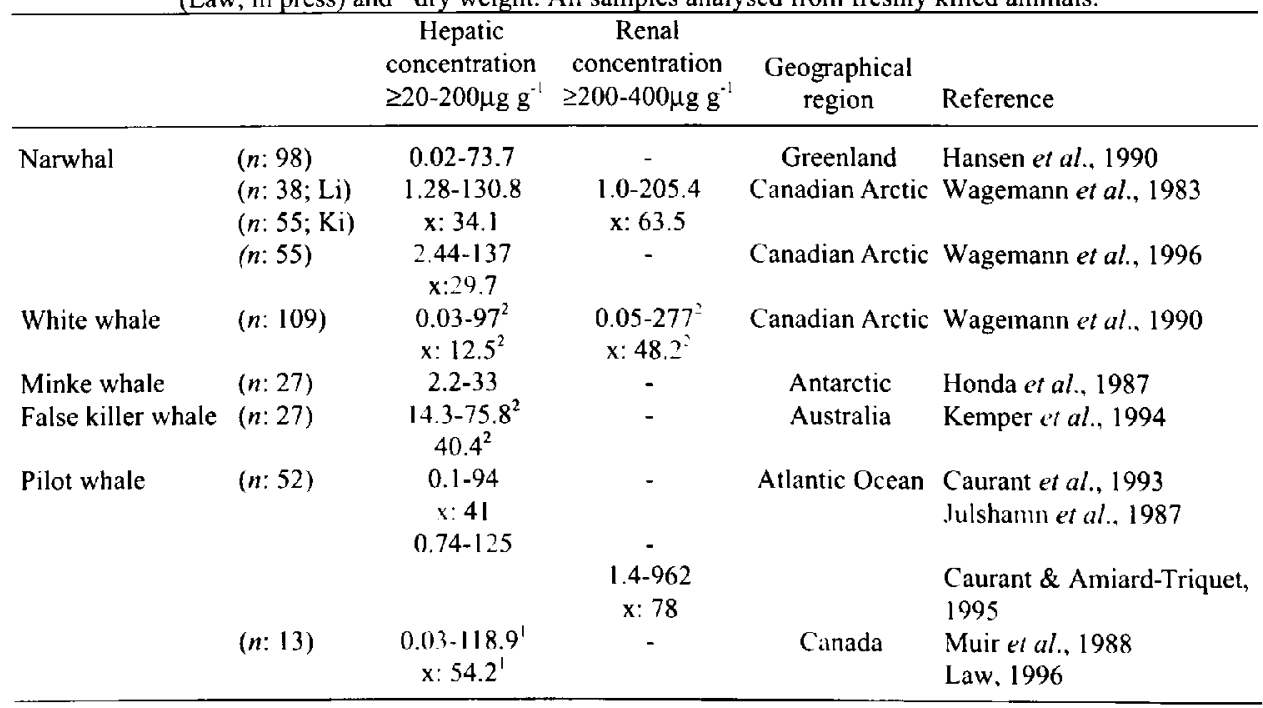


attributed to contamination from a lead smelter in the area. In non-cetacean species, lead poisoning is associated with the inhibition of enzyme systems, renal damage and cardiac disease (Quarterman, 1986).

\section{REGIONAL DIFFERENCES IN BIOCONCENTRATIONS}

The regional concentration of a metal, and thus its availability to marine biota, is dependent on the source of the metal and its method of transportation to and within the marine environment. Any localised high concentrations of metals will be important in determining levels of transfer to species whose range includes such regions. Thus, metals derived from anthropogenic sources in the form of fossil fuel combustion emissions (e.g. lead) show higher concentrations in areas close to the shoreline source (Davis, 1993; Herut et al., 1993). Coastal concentrations are also high for those metals deposited by riverine transportation (e.g. manganese, aluminium and copper), which tend to show high levels close to and a rapid decrease away from the source.

Only a comparison of metal concentrations from the same tissues or organs and from similar species and comparable habitats, can provide data for a preliminary analysis of geographical differences in metal levels. Even attempts to identify 'hot spots' from metal concentrations in cetaceans can only be tentative due to the other, often uncontrolled, factors that affect concentration levels, particularly the influence of diet. For instance, cadmium concentrations in narwhals from Baffin Bay were 100 times higher than those for white-beaked dolphins from Newfoundland, whilst lead concentrations were 40 times lower; dietary rather than higher background pollution levels were considered responsible for these differences (Muir et al., 1988). Lima and Sequeira (1993) also showed that mercury concentrations in common dolphins from the Portuguese coast were lower than those found in the Mediterranean, where the main prey species, sardines (Sardinus pilchardus), contained very low mercury levels.

Differences have also been reported in concentrations of mercury from species caught in the same place. As Table 10 shows, mean liver concentrations of mercury in adult long-finned pilot whales (Globicephala melas) caught in the Faroe Islands in 1977 was 280.2 $\mu \mathrm{g} \cdot \mathrm{g}^{-1}$ but data from animals caught in 1978 showed a decline to a fifth of the previous years figure, 53.4 $\mu \mathrm{g} \cdot \mathrm{g}^{-1}$ (Julshamn et al., 1987). This decline is also reflected in the mean muscle levels of mercury which in 1978 averaged $1.8 \mu \mathrm{g} \cdot \mathrm{g}^{-1}$, almost half the mean of $3.3 \mu \mathrm{g} \cdot \mathrm{g}^{-1}$ recorded in the previous year. The cause of this discrepancy may be due to discrete populations of pilot whales feeding on different prey items rather than a change in the background pollutant levels of mercury (Julshamn et al., 1987). Further differences were reported by Caurant et al. (1993) on two schools of pilot whales caught in the same place both in 1986. These showed large differences in mean mercury concentrations in the liver $\left(52.1 \mu \mathrm{g} . \mathrm{g}^{-1}\right.$ compared to $\left.84.1 \mu \mathrm{g} . \mathrm{g}^{-1}\right)$. Differences in mercury concentrations from the same geographical area have also been reported for striped dolphins (Itano et al., 1984b).

Despite recognising these sources of variation, Table 10 presents data on the hepatic concentrations of mercury in seven cetacean species from eight regions in an attempt to tentatively identify certain 'hot spots' where reported concentrations of mercury are significantly higher.

Extremely high levels of mercury have been recorded in stranded striped $\left(1,544 \mu \mathrm{g} . \mathrm{g}^{-1}\right.$ ww) and bottlenose $\left(3,828 \mu \mathrm{g} . \mathrm{g}^{-1} \mathrm{ww}\right)$ dolphins from the Mediterranean Sea (André et al., 1991; Leonzio et al., 1992; Law, 1996). The reasons for the high levels recorded in cetaceans from the Mediterranean Sea is likely to be a combination of anthropogenic causes and the high level of background geological mercury levels present in the area (Augier et al., 1993). 
Table 10

A geographical comparison of mercury concentrations in the liver of eight toothed cetacean species $\left(\mu g . g^{-1}\right)$. '= median value, ND: no data reported. All values are dry weight except ' which has been converted from dry weight and ${ }^{2}$ which is dry weight.

\begin{tabular}{llccl}
\hline Species & Region & $\begin{array}{c}\text { Range } \\
\text { (where known) }\end{array}$ & Mean & Study \\
\hline $\begin{array}{l}\text { Striped dolphin } \\
(n: 35)\end{array}$ & Mediterranean & $48-1,613$ & $474.0^{\prime}$ & Augier et al., 1993 \\
$\begin{array}{l}\text { Striped dolphin } \\
(n: 45)\end{array}$ & NW Pacific & $1.7-485$ & 205.0 & Honda et al., 1983 \\
$\begin{array}{l}\text { Pantropical spotted dolphin } \\
(n: 44)\end{array}$ & ET Pacific & $0.18-218$ & 62.7 & André et al., 1990 \\
$\begin{array}{l}\text { Long-finned pilot whale } \\
(n: 14)\end{array}$ & Faroe islands & ND & 280.0 & Julshamn et al., 1987 \\
$\begin{array}{l}\text { Narwhal } \\
(n: 98)\end{array}$ & Arctic & $0.01-42.8$ & $5.26^{*}$ & Hansen et al., 1990 \\
$\begin{array}{l}\text { Harbour porpoise } \\
(n: 36)\end{array}$ & Irish Sea & $0.6-190$ & 20.5 & Law et al., 1992 \\
$\begin{array}{l}\text { Bottlenose dolphin } \\
(n: 1)\end{array}$ & SW Atlantic & ND & 86.0 & Marcovecchio et al., 1990 \\
$\begin{array}{l}\text { White-beaked dolphin } \\
(n: 27)\end{array}$ & NW Atlantic & $0.13-1.6$ & $3.0^{2}$ & Muir et al., 1988 \\
\hline
\end{tabular}

Similarly there appears to be a relationship between the high levels recorded and anthropogenic sources in the western North Pacific. Mercury input into the ocean from Japanese chlor-alkali production in 1970 alone amounted to 650 tons, and a correlation has been reported between the increasing amount of industrial waste inputs into the marine environment and the levels of metals present in the sediments (Goto, 1973; André et al., 1991).

Law et al. (1992) have identified another 'hot spot' in the Irish Sea. Inputs from a variety of industrial sources, particularly from local phosphate plants, raised levels of cadmium in seawater in the area to about 50 times higher than that found in the open ocean, and levels of zinc and lead to ten times higher (Forstner, 1980). This explains the relatively high concentrations of metals in cetaceans from the eastern Irish Sea, for example those found in harbour porpoises (Table 10), which continue to remain high despite a reduction in inputs in the past 10 years (Law et al., 1991; 1992).

\section{CONCLUSIONS}

In the first published overview of metals in marine mammals, Wagemann and Muir (1984) reviewed 16 different studies on 14 cetacean species. In the ten years subsequent to this review this database has increased to over 70 studies on 26 different species (the major ones are shown in Appendix 1). Some of the difficulties outlined at the start of this review continue to apply. Studies still tend to be limited to odontocetes, mercury concentrations and soft tissues. Comparison of concentrations between different species is still difficult because of the number of uncontrolled variables that can affect the levels reported. Different analytical techniques increase the difficulty, although there have been calls to establish a more standardised and coordinated approach (Kuiken and Hartmann, 1991; Kemper et al., 1994) and several long-term studies using consistent techniques have recently been published (Law, 1994; Marcovecchio et al., 1994; Miyazaki, 1994). 
The increase in data has resulted in definite trends being established for the accumulation of many metals within the cetacean body. There is a large database on the site specificity of metal concentrations within the animal. Most metals accumulate in the soft tissues, particularly in the liver and kidney. Since 1984, new information has shown that the highest concentrations of zinc and lead have been found in hard tissues such as the skin and bone, and that concentrations of certain metals are transferred between the female and her young. New data have also been recorded on bioaccumulation rates throughout the food chain. Although this is limited to certain metals, studies to date show that only mercury biomagnifies at each level of the food chain.

Wagemann and Muir (1984) stated that systematic differences were not apparent in metal concentrations but, since then, new data have revealed both regional and species differentiation in concentrations of metals. Many of these are due to differences in background levels of metals and diet. Baleen whale species have lower concentrations of the majority of metals due to a shorter food chain and the fact that they feed lower in the trophic chain than odontocetes (O'Shea and Brownell, 1994).

In the past decade, information on detoxification has improved. It is now known that the positive correlation between mercury, probably the most toxic metal, and selenium results in a detoxification of the organic mercury into a storable compound. Metallothioneins can also reduce damage to cells by binding the toxic metals. Toxicity will occur in a species when the accumulation rate is greater than the combined detoxification, excretion or storage rates, but the actual levels of concentration needed for toxicity to occur are still unknown for most metals or species. Tentative ranges have been proposed for tolerance levels of hepatic and renal mercury and cadmium concentrations, and there are several examples of species which have concentrations exceeding these limits. A possible causal link between high mercury levels and liver disease has been suggested in two study groups of animals (Rawson et al., 1993: Caurant et al., 1994). There may also be a causal link between high levels of metals and 'die-offs' (André et al., 1991; Béland et al., 1992; 1993). Although the effects of these concentrations according to variables such as the species, age and sex, have yet to be established. the available data suggests that high levels of metals have an impact on at least some cetacean species.

\section{ACKNOWLEDGEMENTS}

Dr S. Pullen, WWF-UK and Dr K. Brown, University of Durham, gave invaluable assistance in the preparation of this review. Dr R. Law, Directorate of Fisheries Research, UK Ministry of Agriculture, Fisheries and Food and M. Simmonds, University of Greenwich, UK, provided useful comments on an earlier draft of this paper. Two anonymous referees also gave comments on the paper. Finally, thanks are due to the IWC Secretariat for their help in the final preparation of this paper and for providing answers to endless questions.

\section{REFERENCES}

Andersen, S.H. and Rebsdorff, A. 1976. Polychlorinated hydrocarbons and heavy metals in harbour porpoise (Phocoena phocoena) and white-beaked dolphin (Lagenorhynchus albirostris) from Danish waters. Aquat. Mamm. 4(1):14-20.

André, J.M., Ribeyre, F. and Boudou, A. 1990. Mercury contamination levels and distribution in tissues and organs of Delphinids (Stenella attenuata) from the Eastern Tropical Pacific, in relation to biological and ecological factors. Mar. Environ. Res. 30:43-72.

André, J.M., Boudou, A., Ribeyre, F. and Bernhard, M. 1991. Comparative study of mercury accumulation in dolphins (Stenella coeruleoalba) from French Atlantic and Mediterranean coasts. Sci. Total Environ. 104:191-209.

Arima, S. and Nagakura, K. 1979. Mercury and selenium content of the Odontoceti. Bull. Jpn Soc. Sci. Fish. 45(5):623-6. 
Augier, H., Park, W.K. and Ronneau, C. 1993. Mercury contamination of the striped dolphin, Stenella coeruleoalba, Meyen from the French Mediterranean coasts. Mar. Poll. Bull. 26(6):306-10.

Becker, P.R., Mackey, E.A., Demiralp, R., Suydam, R., Early, G., Koster, B.J. and Wise, S.A. 1995. Relationship of silver with selenium and mercury in the liver of two species of toothed whales (Odontocetes). Mar, Poll. Bull. 30(4):262-71.

Béland, P., de Guise, S. and Plante, R. 1992. Toxicology and pathology of St. Lawrence marine mammals. Final Report, Wildlife Toxicology Fund, St Lawrence National Institute of Ecotoxicology, World Wildlife Fund, Toronto. 95pp. [Available from the author].

Béland, P., de Guise, S., Girard, C., Lagacé, A., Martineau, D., Michaud, R., Muir, D.C.G., Norstrom, R.J., Pelletier, E., Ray, S. and Shugart, L.R. 1993. Toxic compounds and health and reproductive effects in St Lawrence beluga whales. J. Gt Lakes Res. 19(4):766-75.

Bligh, E.G. and Armstrong, F.A.J. 1971. Marine mercury pollution in Canada. ICES C.M. 1971/E 34. Fisheries Improvement Committee. [Available from the author].

Borrell, A. and Aguilar, A. 1999. A review of organochlorine and metal pollutants in marine mammals from Central and South America. J. Cetacean Res. Manage. (Special Issue 1): 195-207.

Bratton, G.R., Spainhour, C.B., Flory, W., Reed, M. and Jayko, K. 1993. Presence and potential effects of contaminants. pp. 701-44. In: J.J. Burns, J.J. Montague and C.J. Cowles (eds.) Special Publication. No. 2. The Bowhead Whale. 1st. Edn. Society for Marine Mammalogy, Lawrence, Kansas.

Byrne, C., Balsubramanian, R., Overton, E.B. and Albert, T. 1985. Concentrations of trace metals in the bowhead whale. Mar. Poll. Bull. 16:497-8.

Cannella, E.J. and Kitchener, D.J. 1992. Differences in mercury levels in female sperm whales, Physeter macrocephalus (Cetacea: Odontoceti). Aust. Mammal. 15:121-3.

Capelli, R., De Pellegrini, R., Mingani, V. and Poggi, R. 1989. Preliminary results on the presence of inorganic, organic mercury and selenium in striped dolphins Stenella coeruleoalba from the Ligurian Sea. Eur. Res. Cetaceans [Abstracts] 3:19-24.

Carlini, R. and Fabbri, F. 1989. Mercury, methylmercury and selenium in Italian stranded odontocetes. Eur. Res. Cetaceans [Abstracts] 3:25-8.

Caurant, F. and Amiard-Triquet, C. 1995. Cadmium contamination in pilot whales Globicephala melas: Source and potential hazard to the species. Mar. Poll. Bull. 30(3):207-10.

Caurant, F. and Navarro, M. 1994. Cadmium and mercury transfer during pregnancy in the marine mammal, long-finned pilot whale (Globicephala melas) of the Faroe Islands. Eur. Res. Ceraceans [Abstracts] $8: 226$.

Caurant, F., Amiard-Triquet, C. and Amiard, J.C. 1993. Factors influencing the accumulation of metals in pilot whales (Globicephala melas) off the Faroe Islands. Rep. int. Whal. Commn (special issue) $14: 369-90$.

Caurant, F., Bloch, D., Moreau, A., Ballan-Dufrancais, C. and Algoet, M. 1994. Histo-pathology of kidney and liver tissues of the pilot whales off the Faroe Islands, related with high levels of cadmium and mercury. Paper SC/46/RP4 presented to the IWC Scientific Committee, May 1994, (unpublished). [Available from the Office of the International Whaling Commission].

Clausen, B. and Andersen, S. 1988. Evaluation of bycatch and health status of the harbour porpoise (Phocoena phocoena) in Danish waters. Dan. Rev. Game Biol. 13(5):1-20.

Davis, J. 1993. Contamination of coastal versus open ocean surface water. Mar. Poll. Bull. 26:128-34.

Dietz, R., Nielsen, C.O., Hansen, M.H. and Hansen, C.T. 1990. Organic mercury in Greenland birds and mammals. Sci. Total Environ. 95:41-51.

Eisler, R. 1984. Trace metal changes with age of marine vertebrates. Biol. Trace Elem. Res. 6:165-80.

Falconer, C.R., Davies, 1.M. and Topping, G. 1980. Selected trace metals in porpoises (Phocoena phocoena) from the north east coast of Scotland. ICES CM 1980/E42. [Available from the author].

Falconer, C.R., Davies, I.M. and Topping, G. 1983. Trace metals in the common porpoise, Phococna phocoena. Mar. Emiron. Res. 8:119-27.

Focardi, S., Marsili, L., Leonzio, C., Zanardelli, M. and Notarbartolo di Sciara, G. 1992. Organochlorines and trace elements in skin biopsies of fin whale, Balaenoptera physalus, and striped dolphin. Stenella coeruleoalha. Eur. Res. Cetaceans [Abstracts] 6:230-3.

Forstner, U. 1980. Inorganic pollutants, particularly heavy metals in estuaries. pp.307-349. In: E. Olausson and I. Cato (eds.) Chemistry and Biogeochemistry of Estuaries. John Wiley, New York. 452pp.

Fujise, Y., Honda, K., Tatsukawa, R. and Mishima, S. 1988. Tissue distribution of heavy metals in Dall's porpoise in the northwestern Pacific. Mar. Poll. Bull. 19(5):226-30.

Furness, R.W. and Rainbow. P.S. (eds.). 1990. Heary Merals in the Marine Environment. CRC Press, Boca Raton, FL. 256pp.

Gaskin. D.E.. Ishida. K. and Frank. R. 1972. Mercury in harbour porpoises (Phocoena phocoena) from the Bay of Fundy region. J. Fish. Res. Board Can. 29(11):1644-6. 
Gaskin, D.E., Smith, G.J.P., Amold, P.W., Louisy, M.V., Frank, R., Holdrinet, M. and McWade, J.W. 1974. Mercury, DDT, Dieldrin and PCB in two species of Odontoceti (Cetacea) from St Lucia, Lesser Antilles. J. Fish. Res. Board Can. 30(3):471-5.

Gaskin, D.E., Stonefield, K.I., Suda, P. and Frank, R. 1979. Changes in mercury levels in Harbor porpoises from the Bay of Fundy, Canada and adjacent waters during 1969-1977. Arch. Environ. Contam. Toxicol. 8:733-62.

George, S.G. 1990. Biochemical and cytological assessment of metal toxicity in marine animals. pp.123-142. In: W. Fumess and P.W. Rainbow (eds.) Heavy Metals in the Marine Environment. CRC Press, Boca Raton, Florida. 256pp.

Gerpe, M., Marcovecchio, J., Moreno, J., Rodriguez, D. and Bastida, R. 1993. Zinc and cadmium relationship in Delphinus delphis. Paper submitted to the 10th Biennial Conference on the Biology of Marine Mammals Texas, USA, November 1993 (unpublished). [Available from the author].

Goto, M. 1973. Inorganic chemicals in the environment - with special reference to the pollution problems in Japan. Environ. Qual. \& Safety 2:72-7.

Hansen, C.T., Nielsen, C.O., Dietz, R. and Hansen, M.M. 1990. Zinc, cadmium, mercury and selenium in minke whales, belugas and narwhals from West Greenland. Polar Biol. 10:529-39.

Hapke, H.-J. 1991. Metal accumulation in the food chain and load of feed and food. pp.319-347. $\ln$ : E. Merian (ed.) Metals and their Compounds in the Environment. VCH, New York. 1,438pp.

Harms, U., Drescher, H.E. and Huschenbeth, E. 1977. Further data on heavy metals and organochlorines in marine mammals from German coastal waters. Meeresforschung 26(3-4):153-61.

Haubold, E.M., Cowan, D., Okorodudu, A.O., Ferrel, S., Christopher, T. and Tripp, A.R. 1993. Heavy metals in vertebrae of Tursiops truncatus stranded along the Texas coast. Paper submitted to the 10th Biennial Conference on the Biology of Marine Mammals, Texas, USA, November 1993 (unpublished). [Available from the author].

Herut. B., Homung, H., Krom, M.D., Kress, N. and Cohen, Y. 1993. Trace metals in shallow sediments from the Mediterranean coastal region of Israel. Mar. Poll. Bull. 26:675-82.

Honda, K. and Tatsukawa, R. 1983. Distribution of cadmium and zinc in tissues and organs, and their age related changes in striped dolphins, Stenella coeruleoalba. Arch. Environ. Contam. Toxicol. 15:543-50.

Honda, K., Tatsukawa, R., Itano, K., Miyazaki, N. and Fujiyama, T. 1983. Heavy metal concentrations in muscle, liver and kidney tissue of striped dolphin, Stenella coeruleoalba, and their variations with body length, weight, age and sex. Agric. Bial. Chem. 47(6):1,219-28.

Honda, K., Fujise, Y. and Tatsukawa, R. 1986a. Age-related accumulation of heavy metals in bone of the striped dolphin, Stenella coeruleoalba. Mar. Environ. Res. 20:143-60.

Honda, K., Yamamota, Y. and Tatsukawa, R. 1986b. Heavy metal accumulation in the livers of Antarctic minke whales, Balaenoptera acutorostrata. Mem. Natl Inst. Polar Res., Japan (Spec. Iss.) 41:10-2.

Honda, K., Yamamoto, Y., Kato, H. and Tatsukawa, R. 1987. Heavy metal accumulations and their recent changes in southem minke whales, Balaenoptera acutorostrata. Arch. Environ. Contam. Toxicol. $16: 209-16$.

Huschenbeth, E. 1977. Ergebnisse Uber Schwermetall und Organohalogenuntersuchungen an verschiedenen Zahnwalen von der Ost und Nordseekuste Schleswig-Holsteins. Inf. Fischwirtsch 24:162-4.

Imperial Oil. 1978. Heavy metals project, Mackenzie Delta and Estuary. A report by Beak Consultants (unpublished). 63pp. [Available from the author].

Itano, K., Kawai, S., Miyazaki, N., Tatsukawa, R. and Fujiyama, T. 1984a. Body burdens and distribution of mercury and selenium in striped dolphins. Agric. Biol. Chem. 48(5):1117-21.

Itano, K., Kawai, S., Miyazaki, N., Tatsukawa, R. and Fujiyama, T. 1984b. Mercury and selenium levels in striped dolphins caught off the Pacific coast of Japan. Agric. Biol. Chem. 48(5):1 109-16.

Jensen, B.A. and Reynolds, J.E. 1993. Copper in liver, kidney and muscle of bottlenose dolphin (Tursiops truncatus) from the Indian River Lagoon system, Florida. Paper presented to the 10th Biennial Conference on the Biology of Marine Mammals Texas, USA, November 1993 (unpublished). [Available from the author].

Johansen, P., Kapel, F.O. and Kraul, I. 1980. Heavy metals and organochlorines in marine mammals from Greenland. Paper C.M. 1980/E: 32. Presented to the Marine Environment Quality Committee of ICES (unpublished). 15pp. [Available from the author].

Joiris, C.R., Bouquegneau, J.M., Delbeke, K. and Overloop, W. 1987. Contamination by stable pollutants (organochlorines and heavy metals) of a common dolphin (Delphinus delphis) found dying in Belgium. Eur. Res. Cetaceans [Abstracts] 1:30-1.

Joiris, C.R., Holsbeek, L., Bouquegneau, J.M. and Bossicart, M. 1991. Mercury contamination of the harbour porpoise Phocoena phocoena and other cetaceans from the North Sea and the Kattegat. Water Air Soil Pollut. 56:283-93. 
Joiris, C.R., Bouquegneau, J.M., Borrens, M., Tavemier, J. and Coignoul, F. 1992a. Heavy metal concentrations and pathology of two harbour porpoises stranded along the Belgium coast. Eur. Res. Cetaceans [Abstracts] 6:222.

Joiris, C.R., Holsbeck, L., Siebert, U., Bouquegneau, M., Duguy, R. and Simmonds, M. 1992b. Heavy metals and organochlorines in common dolphins, Delphinus delphis, stranded along the French Atlantic coast. Eur. Res. Cetaceans [Abstracts] 6:223-6.

Julshamn, K., Andersen, A., Ringdal, O. and Morkore, J. 1987. Trace elements intake in the Faroe Islands. I. Element levels in edible parts of pilot whales (Globicephalus melaena). Sci. Total Environ. 65:53-62.

Kannan, K., Sinha, R.K., Tanabe, S., Ichihashi, H. and Tatsukawa, R. 1993. Heavy metals and organochlorine residues in Ganges river dolphins from India. Mar. Poll. Bull. 26(3):159-62.

Kemper, C., Gibbs, P., Obendorf, D., Marvanek, S. and Lenghaus, C. 1994. A review of heavy metal and organochlorine levels in marine mammals in Australia. Sci. Total Environ. 154(2-3):129-39.

Knap, A.H. and Jickells, T.D. 1983. Trace metals and organochlorines in the Goosebeaked whale. Mar. Poll. Bull. 14(7):271-4.

Koeman, J.H., Peeters, W.H.M., Smit, C.J., Tjioe, P.S. and de Goey, J.J.M. 1972. Persistant chemicals in marine mammals. TNO-Nieuw's 27:570-8.

Koeman, J.H., Peeters, W.H.M., Koudstad-Hol, C.H.M., Tijioe, P.S and de Goeij, J.J.M. 1973. Mercuryselenium correlations in marine mammals. Nature, Lond. 245:385-6.

Kostial, K. 1986. Cadmium. pp.319-347. In: W. Mertz (ed.) Vol. 2. Trace Elements in Human and Animal Nutrition. Academic Press, London. $349 \mathrm{pp}$.

Kuiken, T. and Hartmann, M.G. (eds.). 1991. ECS Newsletter-Special Issue. 17. Proceedings of the first ECS workshop on Cetacean pathology: dissection techniques and tissue sampling'. 1st Edn. European Cetacean Society, Leiden, The Netherlands. 39pp.

Langston, W.J. 1990. Toxic effects of metals and the incidence of metal pollution in the marine ecosystem. In: R.W. Fumess and P.S. Rainbow (eds.) Hear Metals in the Marine Emironment. CRC Press, Boca Raton, Florida. 256pp.

Larsen, B.H. 1995. Parasites and pollutants in seven harbour porpoises (Phocoena phocoena L. 1758) from the Faroe Islands, 1987-1988. Rep. int. Whal. Commn (special issue) 16:223-30.

Law, R.J. 1994. Collaborative UK Marine Mammal Project: summary of data produced 1988-1992. Fisheries Research Technical Report 97, MAFF, Lowestoft, UK. 42pp. [Available from the author].

Law, R.J. 1996. Metals in marine mammals. pp. 357-76. In: W.N. Beyer, G.H. Heinz and A.W. RedmonNorwood (eds.) Environmental Contaminants in Wildlife: Interpreting Tissue Concentrations. CRC Press, Inc., Boca Raton, Florida, USA.

Law, R.J., Fileman, C.F., Hopkins, A.D., Baker, J.R., Harwood, J., Jackson. D.B., Kennedy, S., Martin, A.R. and Morris, R.J. 1991. Concentrations of trace metals in the livers of marine mammals (seals, porpoises and dolphins) from waters around the British Isles. Mar. Poll. Bull. 22(4):183-91.

Law, R.J., Jones, B.R., Baker, J.R., Kennedy, S., Milne, R. and Morris, R.J. 1992. Trace metals in the livers of marine mammals from the Welsh Coast and the Irish Sea. Mar. Poll. Bull. 24(6):296-304.

Law, R.J., Stringer, R.L., Allchin, C.R. and Jones, B.R. 1996. Metals and organochlorines in sperm whales (Physeter macrocephalus) stranded around the North Sea during the 1994/1995 winter. Mar. Poll. Bull. 32( 1$): 72-7$.

Leonzio, C., Focardi, S. and Fossi, C. 1992. Heavy metals and selenium in stranded dolphins of the northern Tyrrhenian (NW Mediterranean). Sci. Total Environ. 119:77-84.

Lima, C. and Sequeira, M. 1993. Mercury in common dolphin (Delphinius delphis) off the Portuguese coast. Eur. Res. Cetaceans [Abstracts] 7:216-9.

Lindberg, S., Stokes, P.M., Goldberg, E. and Wren, C. 1987. Lead, mercury, cadmium and arsenic in the environment. Scope 31:17-34.

Marcovecchio, J.E., Moreno, V.J., Bastida, R.O., Gerpe, M.S. and Rodríguez, D.H. 1990. Tissue distribution of heavy metals in small cetaceans from the southwestern Atlantic Ocean. Mar. Poll. Bull. $21(6): 299-304$.

Marcovecchio, J.E., Gerpe, M.S., Moreno. V.J., Bastida, R.O., Rodriguez, D.H. and Moron, S.G. 1992. Trace metals distribution in a Cuvier's beaked whale, Ziphius cavirostris. pp. 241-4. In: J.P. Vernet (ed.) Envirommental Contamination. CEP Consultants Ltd, Edinburgh, UK.

Marcovecchio, J.E., Gerpe, M.S., Bastida, R.O., Rodríguez, D.H. and Morón, S.G. 1994. Environmental contamination and marine mammals in coastal waters from Argentina: an overview. Si $i$. Tofal Emviron. $154: 141-51$

Marsili, L., Forcada, S., Cuna, D., Leonzio, C., Casini, L., Bortolotto, A. and Stanzani, L. 1992. Chlorinated hydrocarbons and heavy metals in tissues of striped dolphins, Stenella corruleoalba, stranded along the Apulian and Sicilian coasts (summer 1991). Eur. Res. Ceraceans [Abstracts] 6:234-7.

Martineau, D., Lagacé, A., Massé, R., Morin, M. and Béland, P. 1985. Transitional cell carcinoma of the urinary bladder in a beluga whale (Delphinapterus leucas). Com. Vet. I. Res. 26:297-302. 
Martineau, D., Lagacé, A., Béland, P., Higgins, R., Armstrong, D. and Shugart, L.R. 1988. Pathology of stranded beluga whales (Delphinapterus leucas) from St Lawrence Estuary (Québec, Canada). J. Comp. Pathol. 38:287-311.

Martineau, D., De Guise, S., Fournier, M., Shugart, L., Girard, C., Lagacé, A. and Béland, P. 1994. Pathology and toxicology of beluga whales from the St Lawrence estuary, Quebec, Canada - past, present and future. Sci. Total Environ. 154(2-3):201-15.

Martoja, R. and Berry, J.P. 1980. Identification of tiemannite as a probable product of demethylation of mercury by selenium in cetaceans. A complement to the scheme of the biological cycle of mercury. Vie Milieu 30(1):7-10.

Martoja, R. and Viale, D. 1977. Accumulation de granules de seleniure mercurique dans le fois d'Odontocetes (Mammiferes, Cetaces): un mechanisme possible de detoxification du methylmercure par le selenium. C.R. hebd. Seanc. Acad. Sci. Paris, t.285 Series D:109-12.

Meador, J.P., Varanasi, U., Robisch, P.A. and Chan, S.L. 1993. Toxic metals in pilot whales (Globicephala melaena) from strandings in 1986 and 1990 on Cape Cod, Massachusetts. Can. J. Fish. Aquat. Sci. 50(12):2698-706.

Miyazaki. N. 1994. Contaminant monitoring studies using marine mammals and the need for establishment of an International Environmental Specimen Bank. Sci. Total Environ. 154(2-3):249-56.

Morris, R.J., Law, R.J., Allchin, C.R., Kelly, C.A. and Fileman, C.F. 1989. Metals and organochlorines in dolphins and porpoises of Cardigan Bay, West Wales. Mar. Poll. Bull. 20(10):512-23.

Muir, D.C.G., Wagemann, R., Grift, N.P., Norstrom, R.J., Simon, M. and Lien, J. 1988. Organochlorine chemical and heavy metal contaminants in white-beaked dolphins (Lagenorhynchus albirostris) and pilot whales (Glohicephala melaena) from the coast of Newfoundland, Canada. Arch. Environ. Contam. Toxicol. 17:613-29.

Muir, D.C.G., Wagemann, R., Hargrave, B.T., Thomas, D.J., Peakall, D.B. and Norstrom, R.J. 1992. Arctic marine ecosystem contamination. Sci. Total Environ. 122:75-134.

Munday, B.L. 1985. Mercury levels in the musculature of stranded whales in Tasmania. Tas. Fish. Res. $27: 11-3$.

Nagakura, K., Arima, S., Kurihara, M., Koga, T. and Fujita, T. 1974. Mercury content of whales. Bull. Tokai Reg. Fish. Res. Lab. 78:41.

Nigro, M. and Leonzio, C. 1993. Mercury selenide accumulation in dolphins. Eur. Res. Cetaceans [Abstracts] 7:212-5.

O'Shea, T.J. and Brownell, R.L. 1994. Organochlorine and metal contaminants in baleen whales - a review and evaluation of conservation implications. Sci. Total Environ. 154(2-3):179-200.

Overton, E.B., Byme, C., McFall, J.A., Antoine, S.R. and Laseter, J.L. 1983. Preliminary observations on tissue pollutant levels in subsistence harvested bowhead whales (Balaena mysticetus). Paper SC/35/PS17 presented to the IWC Scientific Committee, June 1983 (unpublished). 11 pp. [Available from the Office of the International Whaling Commission].

Paludan-Muller, P., Agger, C.T., Dietz, R. and Kinze, C.C. 1993. Mercury, cadmium, zinc, copper and selenium in harbour porpoise (Phocoena phocoena) from West Greenland. Polar Biol. 13(5):311-20.

Piotrowski, J.K. and Coleman, D.O. 1980. Environmental hazards of heavy metals: summary evaluation of lead, cadmium and mercury. Monitoring and Assessment Research Centre (Report number 20). [Available from the author].

Quarterman, J. 1986. Lead. pp.281-319. In: W. Mertz (ed.) Vol. 2. Trace Elements in Human and Animal Nutrition. Academic, London. 349pp.

Rawson, A.J., Patton, G.W., Hofmann, S., Pietra, G.G. and Johns, L. 1993. Liver abnormalities associated with chronic mercury accumulation in stranded Atlantic bottlenose dolphins. Ecotoxicol. Environ. Saf. 25(1):41-7.

Read, A.J. and Hohn, A.A. 1995. Life in the fast lane: the life history of harbor porpoises from the Gulf of Maine. Mar. Mammal Sci. 11(4):423-40.

Ridlington, J.W., Chapman, D.C., Goeger, D.E. and Whanger, P.D. 1981. Metallothionein and Cu-chelatin: characteristics of metal-binding proteins from tissues of four marine mammals. Comp. Biochem. Physiol. 70B:93-104.

Sanpera, C., Capelli, R., Minganti, V. and Jover, L. 1993. Total and organic mercury in North Atlantic fin whales - distribution pattern and biological related changes. Mar. Poll. Bull. 26(3):135-9.

Schnapp, D. 1993. Individual variation and tissue distribution of mercury and selenium in the harbour porpoise (Phocoena phocoena). Eur. Res. Cetaceans [Abstracts] 7:207-11.

Sergeant, D.E. 1980. Levels of mercury and organochlorine residues in tissues of sea mammals from the $\mathrm{St}$ Lawrence estuary. ICES CM 1980/E:55. [Available from the author].

Simmonds, M.P., Johnston, P.A., French, M.C., Reeve, R. and Hutchinson, J.D. 1994. Organochlorines and mercury in pilot whale blubber consumed by Faroe islanders. Sci. Total Environ. 149(1-2):97-111. 
Stoneburner, D.L. 1978. Heavy metals in tissues of stranded short-finned pilot whales. Sci. Total Environ. 9:293-7.

Szefer, P., Malinga, M., Skora, K. and Pempkowiak, J. 1994. Heavy metals in harbour porpoises from Puck Bay in the Baltic Sea. Mar. Poll. Bull. 28(9):570-1.

Taguchi, M., Yasuda, K., Kurosawa, S. and Storro-Patterson, R. 1980. Mercury levels in whale meat sold in Japan. Paper SC/32/O 11 presented to the IWC Scientific Committee, 1980 (unpublished). 4pp. [Available from the Office of the International Whaling Commission].

Teigen, S.W., Skaare, J.U., Bjørge, A., Degre, E. and Sand, G. 1992. Mercury and selenium in harbour porpoise (Phocoena phocoena) in Norwegian waters. Paper SC/44/SM9 presented to the IWC Scientific Committee, June 1992 (unpublished). $29 \mathrm{pp}$. [Available from the Office of the International Whaling Commission].

Thibaud, Y. and Duguy, R. 1973. Teneur en mercure chez les cétacés des côtes de France. Paper CM N/2 presented to ICES (International Council for the Exploration of the Sea). Unpublished. 8pp. [Available from the author].

Thompson, D.R. 1990. Metal levels in marine vertebrates. pp.143-183. In. R.W. Furness and P.W. Rainbow (eds.) Heavy Metals in the Marine Environment. CRS Press, Boca Raton, FL.

Tohyama, C., Himeno, S.-I., Watanabe, C., Suzuki, T. and Morita, M. 1986. The relationship of the increased level of metallothionein with heavy levels in the tissue of the harbour seal (Phoca vitulina). Ecotoxicol. Environ. Saf. 12:85-94.

Tomita, M. and Nishimura, M. 1973. Studies of mercury contents of whales. Japan J Hyg. 28(1):59.

Underwood, E.J. 1977. Trace Elements in Human and Animal Nutrition. Academic Press, New York. 196pp.

Varanasi, U., Stein, J.E., Tilbury, K.L., Meador, J.P., Sloan, C.A., Clark, R.C. and Chan, S.L. 1994. Chemical contaminants in gray whales (Eschrichtius robustus) stranded along the west coast of North America. Sci. Total Environ. 145(1-2):29-53.

Viale, D. 1974. Divers de la pollution par les metaux chez quelques cetaces de Mediterranee occidentale. Joum. Etud. Poll. 183-91. [In French].

Wagemann, R. and Muir, D.G.C. 1984. Concentrations of heavy metals and organochlorines in marine mammals of northern waters: overview and evaluation. Can. Tech. Rep. Fish. Aquat. Sci. 1279:1-97.

Wagemann, R. and Stewart, R.E.A. 1994. Concentrations of heavy metals and selenium in tissues and some foods of walrus (Odobenus rosmarus rosmarus) from the eastern Canadian Arctic and Sub-Arctic, and associations between metals, age and gender. Cam. J. Fish. Aquat. Sci. 51(2):426-36.

Wagemann, R., Snow, N.B., Lutz, A. and Scott, D.P. 1983. Heavy metals in tissues and organs of the narwhal (Monodon monoceros). Can. J. Fish. Aquat. Sci. 40(2):206-14.

Wagemann, R., Hunt, R. and Klaverkamp, J.F. 1984. Subcellular distribution of heavy metals in liver and kidney of a narwhal whale (Monodon monoceros): an evaluation for the presence of metallothionein. Comp. Biochem. Physiol. 78(2):301-7.

Wagemann, R., Stewart, R.E.A., Béland, P. and Desjardins, C. 1990. Heavy metals and selenium in tissues of beluga whales, Delphinapterus leucas, from the Canadian Arctic and the St Lawrence Estuary. pp. 191-206. In: T.G. Smith, D.J. St Aubin and J.R. Geraci (eds.) Advances in Research on the Beluga Whale, Delpinapterusleucas. Can. Bull. Fish. Aquatic Sci. 224. 206pp.

Wagemann, R., Innes, S. and Richard, P.R. 1996. Overview and regional and temporal differences of heavy metals in Arctic whales and ringed seals in the Canadian Arctic. Sci. Total Environ. 186:41-66.

Editors' note: The paper of Henry and Best (pp. 177-94 in this volume) arrived too late for inclusion in this review. 


\section{Appendix 1}

Summary of species, metals and geographical areas covered in this review.

\begin{tabular}{|c|c|c|c|c|}
\hline Species & Metal & Tissue/Organ & Area & No. \\
\hline \multicolumn{5}{|l|}{ MYSTICETI } \\
\hline Minke whale, & $\mathrm{Hg}, \mathrm{Cd}, \mathrm{Zn}, \mathrm{Cu}, \mathrm{Pb}, \mathrm{Fe}, \mathrm{Mn}$ & $\mathrm{Li}$ & Ant & 1 \\
\hline \multirow[t]{7}{*}{ Balaenoptera acutorostrata } & $\mathrm{Hg}, \mathrm{Cd}, \mathrm{Se}, \mathrm{Zn}$ & $\mathrm{Li}, \mathrm{Ki}, \mathrm{Mu}$ & GD & 2 \\
\hline & $\mathrm{Cd}$ & $\mathrm{Li}, \mathrm{Ki}, \mathrm{Blu}$ & GD & 32 \\
\hline & $\mathrm{Hg}$ & $\mathrm{Li}, \mathrm{Mu}$ & GD & 6 \\
\hline & $\mathrm{Hg}$ & $\mathrm{Li}, \mathrm{Ki}, \mathrm{Mu}$ & GD & 34 \\
\hline & $\mathrm{Hg}, \mathrm{Cd}, \mathrm{Zn}, \mathrm{Cu}, \mathrm{Pb}, \mathrm{Cr}$ & $\mathrm{Li}$ & UK & 11 \\
\hline & $\mathrm{Hg}$ & $\mathrm{Mu}$ & NWP & 49 \\
\hline & $\mathrm{Hg}$ & $\mathrm{Mu}$ & NWP & 50 \\
\hline Sei whale, & $\mathrm{Hg}$ & $\mathrm{Mu}$ & $\mathrm{SP}$ & 5 \\
\hline Balaenoptera borealis & $\mathrm{Hg}$ & $\mathrm{Mu}$ & NWP & 49 \\
\hline Bowhead whale, & $\mathrm{Hg}, \mathrm{Cd}, \mathrm{Se}, \mathrm{Zn}, \mathrm{Cu}, \mathrm{Pb}, \mathrm{Ni}, \mathrm{Ag}$ & $\mathrm{Li}, \mathrm{Ki}, \mathrm{Mu}, \mathrm{Blu}$ & AS & 17 \\
\hline \multirow[t]{3}{*}{ Balaena mysticetus } & $\mathrm{Hg}$ & $\mathrm{Li}, \mathrm{Ki}, \mathrm{Mu}, \mathrm{Blu}$ & AS & 62 \\
\hline & $\mathrm{Hg}, \mathrm{Cd}, \mathrm{Se}, \mathrm{Zn}, \mathrm{Cu}, \mathrm{Pb}, \mathrm{Fe}$ & $\mathrm{Li}, \mathrm{Ki}, \mathrm{Mu}, \mathrm{Blu}$ & AS & 71 \\
\hline & $\mathrm{Ag}$ & $\mathrm{Li}$ & AS & 75 \\
\hline \multicolumn{3}{|l|}{ Balaenoptera edeni } & & 50 \\
\hline Fin whale, & $\mathrm{Hg}$ & $\mathrm{Li}, \mathrm{Ki}, \mathrm{Mu}$ & NEA & 3 \\
\hline \multirow{2}{*}{ Balaenoptera physalus } & $\mathrm{Hg}, \mathrm{Cd}, \mathrm{Pb}$ & $\mathrm{Sk}$ & Med & 4 \\
\hline & $\mathrm{Hg}$ & $\mathrm{Mu}$ & SP & 5 \\
\hline Pygmy right whale, & $\mathrm{Hg}, \mathrm{Cd}, \mathrm{Pb}$ & $\mathrm{Li}, \mathrm{Mu}, \mathrm{Blu}, \mathrm{Bo}$ & Aust & 69 \\
\hline Caperea marginata & & & & \\
\hline $\begin{array}{l}\text { Gray whale, } \\
\text { Eschrichtius robustus }\end{array}$ & $\mathrm{Hg}, \mathrm{Cd}, \mathrm{Se}, \mathrm{Zn}, \mathrm{Cu}, \mathrm{Pb}, \mathrm{Fe}, \mathrm{Ni}, \mathrm{Ag}$ & $\mathrm{Li}, \mathrm{Ki}, \mathrm{Sto}, \mathrm{Br}$ & $\begin{array}{l}\text { AS, } \\
\text { ETP }\end{array}$ & 71 \\
\hline \multicolumn{5}{|l|}{ ODONTOCETI } \\
\hline Sperm whale, & $\mathrm{Hg}$ & $\mathrm{Mu}$ & $\mathrm{Sp}$ & 5 \\
\hline \multirow[t]{8}{*}{ Physeter macrocephalus } & $\mathrm{Hg}$ & $\mathrm{Mu}$ & Ant & 5 \\
\hline & $\mathrm{Hg}$ & $\mathrm{Li}, \mathrm{Mu}$ & NS & 25 \\
\hline & $\mathrm{Hg}$ & $\mathrm{Mu}$ & NWP & 49 \\
\hline & $\mathrm{Hg}$ & $\mathrm{Mu}$ & NWP & 50 \\
\hline & $\mathrm{Hg}, \mathrm{Cd}$ & $\mathrm{Li}$ & NWP & 63 \\
\hline & $\mathrm{Hg}, \mathrm{Cd}, \mathrm{Pb}$ & $\mathrm{Li}, \mathrm{Ki}, \mathrm{Mu}, \mathrm{Blu}$ & Aust & 72 \\
\hline & $\mathrm{Hg}$ & $\mathrm{Mu}$ & Aust & 73 \\
\hline & $\mathrm{Hg}, \mathrm{Cd}, \mathrm{Se}, \mathrm{Zn}, \mathrm{Cu}, \mathrm{Pb}, \mathrm{As}, \mathrm{Ni}, \mathrm{Cr}$ & $\mathrm{Li}$ & UK & 76 \\
\hline \multirow{6}{*}{$\begin{array}{l}\text { Pygmy sperm whale, } \\
\text { Kogia breviceps } \\
\text { Ganges river dolphin, } \\
\text { Platanista gangetica } \\
\text { Franciscana, } \\
\text { Pontoporia blainvillei }\end{array}$} & $\mathrm{Hg}, \mathrm{Cd}, \mathrm{Zn}, \mathrm{Cu}$ & $\mathrm{Li}, \mathrm{Ki}, \mathrm{Mu}, \mathrm{Blu}$ & SWA & 8 \\
\hline & $\mathrm{Hg}, \mathrm{Cd}, \mathrm{Pb}$ & $\mathrm{Li}, \mathrm{Mu}, \mathrm{Blu}, \mathrm{Bo}$ & Aust & 72 \\
\hline & $\mathrm{Hg}, \mathrm{Cd}, \mathrm{Zn}, \mathrm{Cu}, \mathrm{Pb}, \mathrm{Fe}, \mathrm{Ni}, \mathrm{Cr}$ & $\mathrm{Li}, \mathrm{Ki}, \mathrm{Mu}$ & ID & 7 \\
\hline & & & & \\
\hline & $\mathrm{Hg}, \mathrm{Cd}, \mathrm{Zn}, \mathrm{Cu}$ & Li, Ki, Mu, Blu & SWA & 8 \\
\hline & & $\mathrm{Li}, \mathrm{Ki}, \mathrm{Mu}$ & GD & 2 \\
\hline White whale, & $\begin{array}{l}\mathrm{Hg}, \mathrm{Cd}, \mathrm{Se}, \mathrm{Zn} \\
\mathrm{Hg}, \mathrm{Cd}, \mathrm{Pb}\end{array}$ & $\mathrm{Li}, \mathrm{Ki}, \mathrm{Mu}$ & GD & 34 \\
\hline \multirow[t]{9}{*}{ Delphinapterus leucas } & $\begin{array}{l}\mathrm{Hg}, \mathrm{Cd}, \mathrm{Pb} \\
\mathrm{Hg}\end{array}$ & $\mathrm{Li}, \mathrm{Ki}, \mathrm{Mu}$ & $\mathrm{CA}$ & 32 \\
\hline & $\begin{array}{l}\mathrm{Hg} \\
\mathrm{Hg}\end{array}$ & $\mathrm{Li}, \mathrm{Ki}, \mathrm{Mu}$ & $\mathrm{CA}$ & 42 \\
\hline & $\mathrm{Hg}$ & $\mathrm{Li}, \mathrm{Mu}, \mathrm{Blu}$ & $\mathrm{CA}$ & 44 \\
\hline & $\mathrm{Hg}, \mathrm{Cd}, \mathrm{Se}$ & $\mathrm{Li}$ & SLA & 27 \\
\hline & $\mathrm{Hg}$ & $\mathrm{Li}, \mathrm{Ki}, \mathrm{Mu}$ & SLA & 60 \\
\hline & $\mathrm{Hg}, \mathrm{Cd}, \mathrm{Se}, \mathrm{Zn}, \mathrm{Cu}, \mathrm{Pb}$ & $\mathrm{Li}, \mathrm{Ki}, \mathrm{Mu}$ & $\mathrm{SLA} / \mathrm{C}$ & 33 \\
\hline & $\mathrm{Hg}, \mathrm{Se}, \mathrm{Ag}$ & $\mathrm{Li}$ & A & 75 \\
\hline & $\mathrm{Hg}, \mathrm{Cd}, \mathrm{Se}, \mathrm{Zn}, \mathrm{Cu}, \mathrm{Pb}$ & $\mathrm{Li}, \mathrm{Ki}, \mathrm{Mu}, \mathrm{Sk}$ & AS & 78 \\
\hline & & & $\mathrm{CA}$ & \\
\hline
\end{tabular}




\begin{tabular}{|c|c|c|c|c|}
\hline Species & Metal & Tissue/Organ & Area & No. \\
\hline Narwhal, & $\mathrm{Hg}, \mathrm{Cd}, \mathrm{Se}, \mathrm{Zn}$ & $\mathrm{Li}, \mathrm{Ki}, \mathrm{Mu}$ & GD & 2 \\
\hline \multirow{5}{*}{ Monodon monoceras } & $\mathrm{Hg}$ & $\mathrm{Li}, \mathrm{Ki}, \mathrm{Mu}$ & GD & 34 \\
\hline & $\mathrm{Hg}, \mathrm{Cd}, \mathrm{Se}, \mathrm{Zn}, \mathrm{Cu}, \mathrm{Pb}, \mathrm{As}$ & $\mathrm{Li}, \mathrm{Ki}, \mathrm{Mu}, \mathrm{Blu}$ & $\mathrm{CA}$ & 20 \\
\hline & $\mathrm{Hg}$ & $\mathrm{Li}, \mathrm{Ki}, \mathrm{Mu}$ & $\mathrm{CA}$ & 42 \\
\hline & $\mathrm{Hg}, \mathrm{Cd}, \mathrm{Zn}, \mathrm{Cu}$ & $\mathrm{Li}, \mathrm{Ki}$ & $\mathrm{CA}$ & 64 \\
\hline & $\mathrm{Hg}, \mathrm{Cd}, \mathrm{Se}, \mathrm{Zn}, \mathrm{Cu}, \mathrm{Pb}$ & $\mathrm{Li}, \mathrm{Ki}, \mathrm{Mu}, \mathrm{Sk}$ & CA & 78 \\
\hline $\begin{array}{l}\text { Harbour porpoise, } \\
\text { Phocoena phocoena }\end{array}$ & $\mathrm{Hg}$ & $\mathrm{Li}, \mathrm{Mu}$ & $\mathrm{CA}$ & 19 \\
\hline \multirow{21}{*}{ Phocoena phocoena } & $\mathrm{Hg}$ & $\mathrm{Li}, \mathrm{Ki}, \mathrm{Mu}$ & $\mathrm{CA}$ & 24 \\
\hline & $\mathrm{Hg}, \mathrm{Cd}, \mathrm{Se}, \mathrm{Zn}, \mathrm{Cu}$ & $\mathrm{Li}, \mathrm{Ki}, \mathrm{Mu}, \mathrm{Sk}$ & GD & 10 \\
\hline & $\mathrm{Hg}, \mathrm{Cd}, \mathrm{Zn}, \mathrm{Cu}, \mathrm{Pb}, \mathrm{Cr}$ & $\mathrm{Li}$ & UK & 11 \\
\hline & $\mathrm{Hg}, \mathrm{Cd}, \mathrm{Zn}, \mathrm{Cu}, \mathrm{Pb}, \mathrm{Ni}, \mathrm{Cr}$ & $\mathrm{Li}$ & UK & 15 \\
\hline & $\mathrm{Hg}, \mathrm{Cd}, \mathrm{Se}, \mathrm{Zn}, \mathrm{Cu}, \mathrm{Pb}, \mathrm{Ni}$ & $\mathrm{Li}, \mathrm{Ki}$ & UK & 66 \\
\hline & $\mathrm{Hg}, \mathrm{Cd}, \mathrm{Zn}, \mathrm{Cu}, \mathrm{Pb}$ & $\mathrm{Li}, \mathrm{Ki}, \mathrm{Br}$ & UK & 18 \\
\hline & $\mathrm{Hg}, \mathrm{Cd}, \mathrm{Zn}, \mathrm{Cu}, \mathrm{Pb}, \mathrm{Ni}, \mathrm{Cr}$ & $\mathrm{Li}, \mathrm{Mu}, \mathrm{Blu}$ & UK & 35 \\
\hline & $\mathrm{Hg}, \mathrm{Cd}, \mathrm{Pb}$ & $\mathrm{Li}, \mathrm{Ki}, \mathrm{He}, \mathrm{Sp}, \mathrm{Br}$ & UK & 22 \\
\hline & $\mathrm{Hg}, \mathrm{Se}$ & $\mathrm{Mu}$ & UK & 53 \\
\hline & $\mathrm{Hg}$ & $\mathrm{Li}, \mathrm{Ki}, \mathrm{Mu}$ & NS & 25 \\
\hline & $\mathrm{Hg}$ & $\mathrm{Li}, \mathrm{Mu}$ & NS & 43 \\
\hline & $\mathrm{Hg}, \mathrm{Cu}, \mathrm{Pb}, \mathrm{Zn}$ & $\mathrm{Li}, \mathrm{Mu}, \mathrm{Blu}$ & NS & 45 \\
\hline & $\mathrm{Hg}, \mathrm{Cd}, \mathrm{Zn}, \mathrm{Cu}, \mathrm{Pb}$ & $\mathrm{Li}, \mathrm{Ki}, \mathrm{Mu}$ & NS & 46 \\
\hline & $\mathrm{Hg}, \mathrm{Cd}, \mathrm{Zn}$ & $\mathrm{Li}, \mathrm{Ki}, \mathrm{Blu}$ & NS & 54 \\
\hline & $\mathrm{Hg}, \mathrm{Se}$ & $\mathrm{Li}, \mathrm{Ki}$ & NY & 14 \\
\hline & $\mathrm{Ag}$ & $\mathrm{Li}$ & AS & 75 \\
\hline & $\mathrm{Hg}, \mathrm{Cd}$ & $\mathrm{Ki}$ & NEA & 79 \\
\hline & $\mathrm{Hg}$ & $\mathrm{Li}, \mathrm{Ki}$ & NEA & 80 \\
\hline & $\mathrm{Hg}, \mathrm{Cd}, \mathrm{Se}, \mathrm{Zn}, \mathrm{As}$ & $\mathrm{Li}, \mathrm{Br}$ & NEA & 81 \\
\hline & $\mathrm{Hg}$ & $\mathrm{Li}, \mathrm{Ki}, \mathrm{Mu}, \mathrm{Blu}, \mathrm{Br}$ & UK & 82 \\
\hline & $\mathrm{Hg}, \mathrm{Cd}, \mathrm{Cu}, \mathrm{Zn}, \mathrm{Pb}, \mathrm{Ni}, \mathrm{Mn}$ & $\mathrm{Li}$ & UK & 83 \\
\hline Dall's porpoise, & $\mathrm{Hg}, \mathrm{Cd}, \mathrm{Zn}, \mathrm{Cu}, \mathrm{Pb}, \mathrm{Fe}, \mathrm{Mn}$ & $\mathrm{Li}, \mathrm{Ki}, \mathrm{Mu}, \mathrm{Sk}, \mathrm{Bl}$ & NWP & 13 \\
\hline \multicolumn{5}{|l|}{ Phocoenoides dalli } \\
\hline White beaked dolphin, & $\mathrm{Hg}, \mathrm{Cd}, \mathrm{Se}, \mathrm{Zn}, \mathrm{Cu}, \mathrm{Pb}, \mathrm{Cr}$ & $\mathrm{Li}, \mathrm{Ki}$ & UK & 66 \\
\hline \multirow[t]{2}{*}{ Lagenorhynchus albirostris } & $\mathrm{Hg}, \mathrm{Cd}, \mathrm{Zn}, \mathrm{Cu}, \mathrm{Pb}, \mathrm{Cr}$ & $\mathrm{Li}$ & UK & 11 \\
\hline & $\mathrm{Hg}, \mathrm{Cd}, \mathrm{Se}, \mathrm{Zn}, \mathrm{Cu}, \mathrm{Pb}$ & $\mathrm{Li}, \mathrm{Ki}, \mathrm{Mu}$ & $\mathrm{AC}$ & 9 \\
\hline White sided dolphin, & $\mathrm{Hg}, \mathrm{Cd}, \mathrm{Se}, \mathrm{Zn}, \mathrm{Cu}, \mathrm{Pb}, \mathrm{Cr}$ & $\mathrm{Li}$ & UK & 66 \\
\hline \multicolumn{5}{|l|}{ Lagenorhynchus acutus } \\
\hline Bottlenose dolphin, & $\mathrm{Hg}, \mathrm{Cd}, \mathrm{Se}, \mathrm{Zn}, \mathrm{Cu}, \mathrm{Pb}, \mathrm{Cr}$ & $\mathrm{Li}, \mathrm{Ki}$ & UK & 66 \\
\hline Tursiops truncatus & $\mathrm{Hg}, \mathrm{Cd}, \mathrm{Zn}, \mathrm{Cu}, \mathrm{Pb}, \mathrm{Cr}$ & $\mathrm{Li}$ & UK & 11 \\
\hline \multirow[t]{9}{*}{ Tursiops gephyreus } & $\mathrm{Hg}, \mathrm{Cd}, \mathrm{Zn}, \mathrm{Cu}$ & $\mathrm{Li}, \mathrm{Mu}, \mathrm{Blu}$ & UK & 35 \\
\hline & $\mathrm{Hg}$ & $\mathrm{Li}, \mathrm{Ki}, \mathrm{Mu}$ & NS & 25 \\
\hline & $\mathrm{Hg}$ & $\mathrm{Li}$ & WA & 26 \\
\hline & $\mathrm{Cu}$ & Li, Ki, Mu & WA & 57 \\
\hline & $\mathrm{Hg}, \mathrm{Cd}, \mathrm{Zn}, \mathrm{Cu}, \mathrm{Pb}$ & Bo & WA & 59 \\
\hline & $\mathrm{Hg}, \mathrm{Cd}, \mathrm{Zn}, \mathrm{Cu}, \mathrm{Pb}, \mathrm{Ni}, \mathrm{Cr}$ & $\mathrm{Li}, \mathrm{Ki}, \mathrm{Mu}, \mathrm{Blu}$ & SWA & 8 \\
\hline & $\mathrm{Hg}, \mathrm{Cd}, \mathrm{Se}, \mathrm{Zn}, \mathrm{Pb}$ & $\mathrm{Li}, \mathrm{Ki}, \mathrm{Mu}$ & Med & 37 \\
\hline & $\mathrm{Hg}, \mathrm{Se}$ & $\mathrm{Li}, \mathrm{Ki}, \mathrm{Mu}, \mathrm{Br}$ & Med & 51 \\
\hline & $\mathrm{Ig}, \mathrm{Cd}, \mathrm{Pb}$ & $\mathrm{Li}, \mathrm{Ki}, \mathrm{Mu}, \mathrm{Blu}, \mathrm{Bo}$ & Aust & 72 \\
\hline Pantropical spotted dolphin, & $\mathrm{Hg}$ & Li, Ki, Mu, Sk, Bo, Blu & ETP & 39 \\
\hline Stenella attenuata & $\mathrm{Hg}, \mathrm{Se}$ & $\mathrm{Mu}$ & NWP & 41 \\
\hline Striped dolphin, & $\mathrm{Hg}, \mathrm{Cd}$ & $\mathrm{Li}, \mathrm{Ki}, \mathrm{Mu}$ & NWP & 12 \\
\hline \multirow[t]{6}{*}{ Stenella coeruleoalba } & $\mathrm{Zn}, \mathrm{Cu}, \mathrm{Pb}, \mathrm{Fe}, \mathrm{Mn}$ & $\mathrm{Li}, \mathrm{Ki}, \mathrm{Mu}, \mathrm{Sk}, \mathrm{Bo}$ & NWP & 30 \\
\hline & $\mathrm{Hg}, \mathrm{Se}$ & $\mathrm{Li}, \mathrm{Ki}, \mathrm{Mu}$ & NWP & 21 \\
\hline & $\mathrm{Cd}, \mathrm{Zn}$ & Bo & NWP & 29 \\
\hline & $\mathrm{Hg}, \mathrm{Se}, \mathrm{Zn}, \mathrm{Cu}, \mathrm{Pb}, \mathrm{Fc}, \mathrm{Mn}$ & Li, Mu, Blu & NWP & 31 \\
\hline & $\mathrm{Hg}, \mathrm{Sc}$ & $\mathrm{Li}, \mathrm{Ki}, \mathrm{Mu}$ & NWP & 41 \\
\hline & $\mathrm{Hg}, \mathrm{Se}$ & $\mathrm{Li}$ & UK & 66 \\
\hline
\end{tabular}




\begin{tabular}{|c|c|c|c|c|}
\hline Species & Metal & Tissue/Organ & Area & No. \\
\hline & $\mathrm{Hg}, \mathrm{Cd}, \mathrm{Se}, \mathrm{Zn}, \overline{\mathrm{Cu}}, \mathrm{Pb}, \mathrm{Cr}$ & $\mathrm{Li}$ & UK & 11 \\
\hline Striped dolphin, & $\mathrm{Hg}, \mathrm{Cd}, \mathrm{Zn}, \mathrm{Cu}, \mathrm{Pb}, \mathrm{Fe}, \mathrm{Mn}$ & $\mathbf{L i}$ & Med & 16 \\
\hline \multirow{7}{*}{$\begin{array}{l}\text { Stenella coeruleoalba } \\
\text { (cont.) }\end{array}$} & $\mathrm{Hg}$ & Li, Ki, Mu, Sk, Blu & Med & 23 \\
\hline & $\mathrm{Hg}$ & $\mathrm{Sk}$ & Med & 4 \\
\hline & $\mathrm{Hg}, \mathrm{Cd}, \mathrm{Pb}$ & $\mathrm{Li}, \mathrm{Ki}, \mathrm{Mu}$ & Med & 37 \\
\hline & $\mathrm{Hg}, \mathrm{Cd}, \mathrm{Se}, \mathrm{Zn}, \mathrm{Pb}$ & $\mathrm{Li}, \mathrm{Ki}$ & Med & 47 \\
\hline & $\mathrm{Hg}, \mathrm{Se}$ & $\mathrm{Li}, \mathrm{Ki}, \mathrm{Mu}, \mathrm{Br}$ & Med & 51 \\
\hline & $\mathrm{Hg}, \mathrm{Se}$ & $\mathrm{Li}, \mathrm{Ki}, \mathrm{Mu}, \mathrm{Sk}$ & Med & 55 \\
\hline & $\mathrm{Hg}, \mathrm{Cd}, \mathrm{Pb}$ & Li, Ki, Mu, Blu & Aust & 72 \\
\hline Common dolphin, & $\mathrm{Hg}, \mathrm{Cd}, \mathrm{Zn}, \mathrm{Cu}, \mathrm{Pb}, \mathrm{Cr}$ & $\mathrm{Li}$ & UK & 11 \\
\hline \multirow[t]{7}{*}{ Delphinus delphis } & $\mathrm{Hg}, \mathrm{Cd}, \mathrm{Se}, \mathrm{Zn}, \mathrm{Cu}, \mathrm{Pb}, \mathrm{Cr}$ & $\mathrm{Li}, \mathrm{Ki}$, Sto & UK & 66 \\
\hline & $\mathrm{Hg}$ & $\mathrm{Li}, \mathrm{Ki}, \mathrm{Mu}$ & NS & 25 \\
\hline & $\mathrm{Hg}$ & Li, Mu, Blu & NS & 65 \\
\hline & $\mathrm{Hg}$ & $\mathrm{Li}, \mathrm{Ki}, \mathrm{Mu}, \mathrm{Blu}, \mathrm{Br}$ & EA & 52 \\
\hline & $\mathrm{Hg}, \mathrm{Cd}, \mathrm{Zn}, \mathrm{Cu}$ & Li, Ki, Mu, Blu & EA & 59 \\
\hline & $\mathrm{Cd}, \mathrm{Zn}$ & $\mathrm{Li}, \mathrm{Ki}, \mathrm{Mu}$ & SWA & 58 \\
\hline & $\mathrm{Hg}, \mathrm{Cd}, \mathrm{Pb}$ & Li, Ki, Mu, Blu, Bo & Aust & 72 \\
\hline $\begin{array}{l}\text { Risso`s dolphin, } \\
\text { Grampus griseus }\end{array}$ & $\mathrm{Hg}, \mathrm{Cd}, \mathrm{Zn}, \mathrm{Cu}, \mathrm{Pb}, \mathrm{Cr}$ & $\mathrm{Li}$ & UK & 66 \\
\hline Long-finned pilot whale, & $\mathrm{Hg}, \mathrm{Cd}, \mathrm{Se}, \mathrm{Zn}, \mathrm{Cu}, \mathrm{Pb}$ & $\mathrm{Li}, \mathrm{Ki}, \mathrm{Mu}$ & $\mathrm{CA}$ & 9 \\
\hline \multirow[t]{6}{*}{ Globicephala melas } & $\mathrm{Hg}, \mathrm{Cd}, \mathrm{Se}, \mathrm{Zn}, \mathrm{Cu}$ & $\mathrm{Li}, \mathrm{Ki}, \mathbf{M u}$ & NEA & 28 \\
\hline & $\mathrm{Hg}, \mathrm{Cd}, \mathrm{Se}, \mathrm{Zn}, \mathrm{Cu}$ & $\mathrm{Li}, \mathrm{Ki}, \mathrm{Mu}$ & NEA & 38 \\
\hline & $\mathrm{Hg}$ & Blu & NEA & 41 \\
\hline & $\mathrm{Cd}$ & $\mathrm{Li}, \mathrm{Ki}, \mathrm{Mu}, \mathrm{Bl}$ & NEA & 74 \\
\hline & $\mathrm{Hg}, \mathrm{Se}$ & Mu & NWP & 41 \\
\hline & $\mathrm{Hg}, \mathrm{Cd}, \mathrm{Se}, \mathrm{Zn}, \mathrm{Cu}, \mathrm{Pb}, \mathrm{Cr}$ & $\mathrm{Li}$ & UK & 66 \\
\hline Short-finned pilot whale, & $\mathrm{Hg}, \mathrm{Cd}, \mathrm{Se}$ & $\mathrm{Li}, \mathrm{Ki}$ & USA & 32 \\
\hline \multirow[t]{2}{*}{ Globicephala macrorhynchus } & $\mathrm{Hg}$ & $\mathrm{Li}, \mathrm{Ki}$ & WI & 40 \\
\hline & $\mathrm{Hg}, \mathrm{Pb}$ & $\mathrm{Li}, \mathrm{Ki}, \mathrm{Mu}$ & Aust & 72 \\
\hline $\begin{array}{l}\text { Killer whale, } \\
\text { Orcinus orca }\end{array}$ & $\mathrm{Hg}, \mathrm{Cd}, \mathrm{Pb}$ & $\mathrm{Li}, \mathrm{Ki}$ & Aust & 72 \\
\hline $\begin{array}{l}\text { False killer whale, } \\
\text { Pseudorca crassidens }\end{array}$ & $\mathrm{Hg}, \mathrm{Cd}, \mathrm{Pb}$ & $\mathrm{Li}, \mathrm{Ki}, \mathrm{Mu}, \mathrm{Blu}$ & Aust & 72 \\
\hline Cuvier's beaked whale, & $\mathrm{Hg}, \mathrm{Se}$ & $\mathrm{Li}$ & NEA & 67 \\
\hline \multirow{2}{*}{ Ziphius cavirostris } & $\mathrm{Hg}, \mathrm{Cd}$ & $\mathrm{Li}, \mathrm{Ki}, \mathrm{Mu}, \mathrm{Blu}$ & WA & 36 \\
\hline & $\mathrm{Hg}, \mathrm{Zn}, \mathrm{Cu}, \mathrm{Pb}, \mathrm{Fe}, \mathrm{Mn}, \mathrm{Ni}$ & $\mathrm{Li}, \mathrm{Ki}, \mathrm{Mu}$ & SWA & 68 \\
\hline $\begin{array}{l}\text { Beaked whale, } \\
\text { Mesoplodon spp }\end{array}$ & $\mathrm{Hg}, \mathrm{Cd}, \mathrm{Pb}$ & $\mathrm{Li}, \mathrm{Ki}, \mathrm{Mu}, \mathrm{Blu}, \mathrm{Bo}$ & Aust & 72 \\
\hline $\begin{array}{l}\text { Bottlenose whale, } \\
\text { Hyperoodon ampullatus }\end{array}$ & $\mathrm{Hg}$ & $\mathrm{Li}, \mathrm{Mu}$ & NS & 43 \\
\hline
\end{tabular}

\section{SITES}

Li: Liver; Ki: Kidney; Mu: Muscle; Blu: Blubber; Bl: Blood; Sk: Skin; Bo: Bone; Br: Brain; Sp: Spleen; He: Heart; Sto: Stomach

\section{GEOGRAPHICAL AREAS}

Ant: Antarctic; AS: Alaska; Aust: Australia; CA: Canada; EA: East Atlantic Ocean; ETP: Eastern Tropical Pacific Ocean; GD: Greenland; ID: India; Med: Mediterranean Sea; NEA: North East Atlantic Ocean; NS: North and Baltic Seas; NWP: North West Pacific Ocean; NY: Norwegian coast; SLA: St Lawrence Seaway, Canada; SP: South Pacific Ocean; SWA: South West Atlantic Ocean; UK: UK coastline; WA: West Atlantic Ocean; WI: West Indies 


\section{STUDIES}

1. Honda et al., 1987; 2. Hansen et al., 1990; 3. Sanpera et al., 1993; 4. Focardi et al., 1992; 5. Nagakura et al., 1974; 6. Johansen et al., 1980; 7. Kannan et al.. 1993; 8. Marcovecchio et al. 1990; 9. Muir et al., 1988; 10. Paludan-Muller et al., 1993; 11. Law et al., 1991; 12. Honda et al., 1983; 13. Fujise et al., 1988; 14. Teigen et al., 1992; 15. Law et al., 1992; 16. André et al., 1991; 17. Byme et al., 1985; 18. Falconer et al., 1983; 19. Gaskin et al., 1972; 20. Wagemann et al., 1983; 21. Honda and Tatsukawa, 1983; 22. Falconer et al., 1980; 23. Augier et al., 1993; 24. Gaskin et al., 1979; 25. Joiris et al., 1991; 26. Rawson et al., 1993; 27. Béland et al., 1992; 28. Julshamn et al., 1987; 29. Honda et al., 1986b; 30. Itano et al., 1984a; 31. Itano et al., 1984b; 32. Stoneburner, 1978; 33. Wagemann et al., 1990; 34 Dietz et al. 1990; 35. Morris et al., 1989; 36. Knap and Jickells, 1983; 37. Leonzio et al., 1992; 38. Caurant et al., 1993; 39. André et al., 1990; 40. Gaskin et al., 1974; 41. Arima and Nagakura, 1979; 42. Bligh and Armstrong, 1971; 43. Huschenbeth, 1977; 44. Imperial Oil, 1978; 45. Andersen and Rebsdorff, 1976; 46. Harms et al., 1977; 47. Capelli et al., 1989; 48. Carlini and Fabbri., 1989; 49. Tomita and Nishimura, 1973; 50. Taguchi et al., 1980; 51. Nigro and Leonzio, 1993; 52. Lima and Sequeira, 1993; 53. Schnapp, D. 1993; 54. Joiris et al., 1992a; 55. Marsili et al., 1992; 56. Simmonds et al., 1994; 57. Jensen and Reynolds, 1993; 58. Gerpe et al., 1993; 59. Haubold et al., 1993; 60. Sergeant, 1980; 61. Joiris et al., 1992b; 62. Overton et al., 1983; 63. Ridlington et al., 1981; 64. Wagemann et al., 1984; 65. Joiris et al., 1987; 66. Law, 1994; 67. Martoja and Viale, 1977; 68. Marcovecchio et al., 1992; 69. Munday, 1985; 70. Bratton et al. 1993; 71. Varanasi et al., 1994; 72. Kemper et al., 1994; 73. Cannella and Kitchener, 1992; 74. Caurant and Amiard-Triquet, 1995; 75. Becker et al, 1995; 76. Law et al., 1996; 77. Meador et al., 1993; 78. Wagemann et al., 1996; 79. Clausen and Andersen, 1988; 80. Larsen, 1995; 81 Koeman et al., 1972; 82. Thibaud and Duguy, 1973; 83. Borrell and Aguilar, 1999; 84. Szefer et al., 1994. 